Summer 2007

\title{
The Law of Society: Governance Through Contract
}

Peter Zumbansen

Osgoode Hall Law School, pzumbansen@osgoode.yorku.ca

Follow this and additional works at: https://www.repository.law.indiana.edu/ijgls

Part of the Contracts Commons, Government Contracts Commons, and the International Law Commons

\section{Recommended Citation}

Zumbansen, Peter (2007) "The Law of Society: Governance Through Contract," Indiana Journal of Global Legal Studies: Vol. 14 : Iss. 2 , Article 2.

Available at: https://www.repository.law.indiana.edu/ijgls/vol14/iss2/2

This Symposium is brought to you for free and open access by the Law School Journals at Digital Repository @ Maurer Law. It has been accepted for inclusion in Indiana Journal of Global Legal Studies by an authorized editor of Digital Repository @ Maurer Law. For more information, please contact rvaughan@indiana.edu.

\section{$\Psi$}

JEROME HALL LAW LIBRARY

INDIANA UNIVERSITY

Maurer School of Law
Bloomington 


\title{
The Law of Society: Governance Through Contract ${ }^{\dagger}$
}

\author{
Peer Zumbansen*
}

\begin{abstract}
This paper focuses on contract law as a central field in contemporary regulatory practice. In recent years, "governance by contract" has emerged as the central concept in the context of privatization, domestic and transnational commercial relations, and law-and-development projects. Meanwhile, as a result of the neo-formalist attack on contract law, "governance of contract" through contract adjudication, consumer protection law, and judicial intervention into private law relations has come under severe pressure. Building on early historical critique of the formalist foundations of an allegedly private law of the market, the paper assesses the current justifications for contractual governance and posits that only an expanded legal realist perspective can adequately explain the complex nature of contractual agreements in contemporary practice. The paper argues for an understanding of contracts as complex societal arrangements that visibilize and negotiate conflicting rationalities and interests.
\end{abstract}

${ }^{\dagger}$ Paper prepared for the 2nd International CLPE Comparative Research in Law \& Political Economy Conference at Osgoode Hall Law School, Toronto, 9-10 November 2006. This paper grows out of a long-standing interest in the public-private interface in contract law, first pursued in my doctoral thesis in Frankfurt and later in collaborative research done with Gralf Calliess during the summer of 2006 at the University of Bremen's Collaborative Research Centre "Transformations of the State." I have greatly benefited from the insightful discussions in the Legal Theory Seminar at Osgoode Hall Law School and from ongoing discussions with Daniela Caruso, Duncan Kennedy, Fernanda Nicola, Anna di Robilant, Robert Wai, Gunther Teubner, Ralf Michaels, David Campbell, Peter Vincent-Jones, Fred Aman, Vaios Karavas, Marc Amstutz, David Synder, Gregory Smith, Fenner Stewart, Elena Cirkovic, Zane Roth, and Maria Panezi. Generous financial support from the Social Sciences and Humanities Research Council of Canada (SSHRC grant no. 4102005-2421) is gratefully acknowledged as is the excellent research assistance of Zane Roth.

- Canada Research Chair and Associate Dean (Research, Graduate Studies, and Institutional Relations), Osgoode Hall Law School, York University, Toronto. Email: Pzumbansen@osgoode. yorku.ca.

Indiana Journal of Global Legal Studies Vol. 14 \#2 (Summer 2007)

CIndiana University School of Law 
"Contracts are the core mechanism whereby the market regulates itself."

"The institution of contract includes irreconcilable ideas and discordant phenomena."

"Contract comes to a lawyer as a term laden with connotations of doctrine and theory."

"The single contract is always already a multiplicity of differing processes, structures, operations." ${ }^{*}$

\section{INTRODUCTION}

\section{A. Contract and Embeddedness}

This paper explores the embeddedness of contractual governance both in institutional and normative terms by situating contractual governance in the contemporary context of post-welfare state privatization politics on the one hand and neo-formalist attacks on policy-driven contract adjudication on the other. Institutionally, contractual governance has been unfolding in a complex, historically grown, and ideologically continually contested regulatory field. The differentiation of various areas and periods of contract law is reflective of this development. At the same time, contractual governance denotes a whole set of conflicting concepts, ideas, and symbols deeply entrenched in theories of society, market, and the state. From this perspective, we are well advised to study contracts in their socio-economic, historical, and cultural context. A careful reading of scholars such as Henry Sumner Maine, Morris Cohen, Robert Hale, Karl Llewellyn, Stewart Macaulay, and Ian Macneil offers a deeper understanding of the institutional and normative dimensions of contractual governance. Their analysis is particularly helpful in assessing ongoing shifts away from a welfare state-based regulation (governance) of contrac-

1. Caroline Bradley, Private International Law-Making for the Financial Markets, 29 Fordham INT'L L.J. 127, 158 (2005).

2. Robert A. Hillman, The Crisis in Modern Contract Theory, 67 Tex. L. Rev. 103, 123 (1988).

3. Karl N. Llewellyn, What Price Contract?-An Essay in Perspective, 40 Yale L.J. 704, 704 (1931).

4. Gunther Teubner, In the Blind Spot: The Hybridization of Contracting, 8 Theoretical InquiRIES L. 51,54 (2007). 
tual relations. ${ }^{5}$ Such shifts are occurring on two levels. First, they take place against the backdrop of a neo-liberal critique of government interference into allegedly private relations. Second, the return to formalism in contract law, which privileges a functionalist, purportedly technical and autonomous, design and execution of contractual agreements over the view of regulated contracts, is linked to a particular concept of sovereignty. The liberation of contractual relations from the regulatory, policy-driven arms of domestic government ${ }^{6}$ is strikingly paralleled by a strong-arm view of state actors in international relations. ${ }^{7}$ What states bargain for, accept, and do becomes the yardstick by which to measure their commitments. Soft law, customary law, or other bodies of compliance-demanding international norms can produce binding commitments comparable to those recognized by state discretion. This realist turn in international law stands in considerable contrast to the (Legal) Realist interpretation of contractual governance in the 1920s and 1930s. In this light, the Legal Realists' contribution, as helpful as it might be in ascertaining the role of courts and ideology in framing, taming, or unleashing market power, seems in need of reconsideration and further conceptualization in the current institutional and normative context by taking a broader perspective on contractual governance.

This paper argues that such a perspective can only be gained by recognizing that the regulatory challenges of both the nation state and the emerging global legal order have their origins in the unsolved question of the "basis of contract." Where globalization has led to a fragmentation, disembeddedness, and transnationalization of contexts and, thus, has challenged the traditional understanding of embeddedness, the task should no longer be to apply a largely nation-state oriented Legal Realist perspective and critique to the sphere of contemporary contractual governance, but, rather, to translate its aims into a more reflexive set of instruments of legal critique. Even if globalization has led to a dramatic denationalization of many regulatory fields and functions, it is still not clear whether and how globalization replaces, complements, or aggravates transformations of societal governance with and through contract.

This paper proceeds by revisiting a few of the observations made by the $1920 \mathrm{~s}$

5. For in-depth analysis of these issues, see David Campbell, Relational Contract and the Nature of Private Ordering: A Comment on Vincent-Jones, 14 Ind. J. Global Legal Stud. 279 (2007); Peter Vincent-Jones, The New Public Contracting: Public Versus Private Ordering?, 14 Ind. J. Global Legal Stud. 259 (2007).

6. See generally Alan Schwartz \& Robert E. Scott, Contract Theory and the Limits of Contract Law, 113 YALE L.J. 541 (2003) (discussing a normative theory of contract law, in which contract law should encourage efficient trade and investment, but do nothing else).

7. Jack L. Goldsmith \& Eric A. Posner, The Limits of International Law 6-10 (2005). 
and 1930s Legal Realists before studying the currency of contractual thinking in the dismantling of the welfare system during the twentieth century. The third part continues this inquiry into the deconstruction of contract law by contract and social norms and contrasts this account with one of de-centered, fragmented society, which poses particular obstacles to any unifying concepts of contractual governance. The last part of the paper attempts to suggest that a reflexive law concept of contractual governance, which reaches beyond the Legal Realists' hope for a re-politicization of contract, might provide for a more adequate assessment of the basis of contract.

\section{B. The Legal Realist Critique of Contract and Property}

\section{Karl Llewellyn and the Contractual Dream of Private Government}

In 1931, shortly after delivering his famous "Bramble Bush" lectures to law students at Columbia Law School, ${ }^{8}$ the provocative American lawyer Karl Llewellyn published what was to become a seminal article in Legal Realist writing on contract law. What Price Contract?-An Essay in Perspective outlined, in not always easily digestible language, lasting elements of a theory of private ordering. In exploring the tension between formal contract rules and societal practice, and relying on legal sociologist work and case law in the area of commercial transactions, Llewellyn explored the potential of a close analysis of legal and non-legal obligations for a more adequate understanding of contractual relations in a market society. His analysis depicted the many ways in which an ever more sophisticated contract law doctrine, elaborated through specialization and adjudication, increasingly led to a juncture between legal and social rules governing private actors' behavior. ${ }^{9}$ Llewellyn recognized contract law's challenge in mastering the development of rules necessary to the regulation of a quickly developing commercial world, bringing the varied interests, starting points, and power relations into sharp relief.

Rereading Llewellyn some seventy years later, one may be struck by the apparently contemporary nature of his observations with regard to present debates over the creation of private legal orders and spontaneous legal systems. ${ }^{10}$ Preced-

8. K.N. Llewellyn, The Bramble Bush: On Our Law and Its Study vii (1930).

9. Llewellyn, supra note 3, at 712-14.

10. Cf. Amitai Aviram, A Paradox of Spontaneous Formation: The Evolution of Private Legal Systems, 22 Yale L. \& Pol'y Rev. 1 (2004) (discussing the need of enforcement mechanisms for a functioning spontaneous private legal system); David V. Snyder, Private Lawmaking, 64 Оноо ST. L.J. 371 (2003) (outlining the conditions under which private law making actors enter into a com- 
ing present-day law and economics (L\&E) contentions as to the need for an efficient contract law regime to facilitate market transactions ${ }^{11}$ as well as work by relational contract scholars on responsive, adaptive long-term relation $\mathrm{s}^{12}$ and on "private government,"13 Llewellyn is sensitive to the challenges to contractual governance in a volatile, fast-evolving society. Recognizing the crucial role that contracts play in "an economy stabilizing itself along new lines," ${ }^{14}$ Llewellyn already pointed to the "constitution-making" dimensions of contractual governance. ${ }^{15}$ It is in the bottom-up creation of contractual rules that Llewellyn sees the laying down of a constitutional order on which contracting parties can fall back. ${ }^{16}$

What makes Llewellyn's piece so relevant for our present inquiry into the basis of contractual governance-meaning both governance by contract and governance of contract, whether by legislation, judicial law making, or private norm and standard setting ${ }^{17}$ - is his awareness of the fragile relationship between contractual self-regulation and the employment of the legal enforcement machin-

petitive process, through which a more efficient, bottom-up law creation may develop); Gunther Teubner, Globale Privatregimes: Neo-spontanes Recht und duale Sozialverfassungen in der Weltgesellschafi, in Zur Autonomie des Individuums: Liber Amicorum Spiros Simitis 437 (Dieter Simon \& Manfred Weiss eds., 2000) (highlighting the ability of private norm creators to satisfy both the need for hierarchical organization and spontaneous evolution).

11. E.g., Richard A. Posner, The Law and Economics of Contract Interpretation, 83 Tex. L. Rev. 1581,1582 (2005) ("The main purpose of contracts is to enable performance to unfold over time without either party being at the mercy of the other, as would be the case if, for example, a buyer could refuse to pay for a custom-built house for which there were no alternative buyers at or above the agreed price."); Steven Shavell, On the Writing and the Interpretation of Contracts, 22 J.L. EcoN. \& ORG. 289, 289 (2006) (arguing that interpreting contracts is superior to enforcing contracts as written).

12. E.g., Peter Vincent-Jones, The New Public Contracting: Regulation, Responsiveness, Relationality 4-11 (2006); David Campbell, The Relational Constitution of Contract and the Limits of 'Economics': Kenneth Arrow on the Social Background of Markets, in Contracts, Co-operation, and Competition: Studies in Economics, Management and Law 307 (Simon Deakin \& Jonathan Michie eds., 1997); Ian R. Macneil, Contracts: Adjustment of Long-Term Economic Relations Under Classical, Neoclassical, and Relational Contract Lat, 72 Nw. U. L. Rev. 854, 889-90 (1978).

13. Stewart Macaulay, Private Government, in Law and the Social Sciences 445 (Leon Lipson \& Stanton Wheeler eds., 1986)

14. Llewellyn, supra note 3 , at 727.

15. Id. at 728.

16. Id. at 730 .

17. For insightful analysis in this respect, see Erich Schanze, Hare and Hedgehog Revisited: The Regulation of Markets That Have Escaped Regulated Markets, $151 \mathrm{~J}$. Institutional \& Theoretical ECoN. [JITE] 162 (1995). 
ery. ${ }^{18}$ What makes this relationship so fragile? Llewellyn points to the "persistent doubt" of courts "as to the wisdom of any interference with men's bargains." ${ }^{19} \mathrm{He}$ observes:

Any attempt by officials to take account of the social implications of agreements, to stir any other policy-flavor at all into the universal soup-stock of 'give 'em what they've called for,' cuts into the broader field of the use of law to enforce or buttress taboos on particular types of conduct. ${ }^{20}$

In fact, what lies at the core of the difficult relationship between self-governance by contract and contract-rights enforcement through law by courts is the degree to which we don't know what begins and ends where. Llewellyn unfolds an intriguing analysis to help us understand, if not where, then how to draw the lines here. Using standardized contracts as an example, he illustrates the powerful impact that the principle of liberty of contract has on the control exercised by courts over such contracts. Starting with the presumption that the bargaining parties are in a better position to ascertain their rights and obligations under the agreement than a court, the principle serves to legitimate eventually very farreaching powers of the bargaining parties. Such powers, Llewellyn observes, will most likely and most often be exercised by those already in a position of superiority. What this observation suggests, however, is that normally, that is in the ordinary case where no outright abuse is being detected or a lawsuit being brought, this power imbalance will be hard to assess, in particular in cases of broadly employed, ubiquitous standard contracts governing daily commercial transactions on a mass basis. As a result, these contracts are taken not so much as an obvious example of duress and unequal bargaining power, but as a more or less ordinary form of organizing business relations in a consumer market.

One can hardly overstate the importance of this point and the ensuing analysis. Llewellyn recognizes standard contracts as an example of how the concept of "legal contract" has found its major importance "to provide a frame-work for well-nigh every type of group organization and for well-nigh every type of passing or permanent relation between individuals and groups, up to and including states...."21 The

18. Llewellyn, supra note 3, at 731.

19. Id. at 732 .

20. Id. at 734 .

21. Id. at 736-37. 
relevance of this concept he sees in providing - both for the contracting parties and the judges deciding cases arising out of such agreements-highly adjustable elements that serve as never fully accurate indicators of real working relations through which at least a rough guide may be won to assess the underlying agreement. Here, the point is that the law of standardized contracts consists of the combination of a set of contract law rules that, together with the assumption of the validity of a principle of liberty of contract, serve to legitimate a private arrangement that in many cases defies that very principle. The thrust of this observation becomes even more apparent when we shift our attention from standard contracts to the realm of "informal promises," 22 an area that would later assume a central role in work done in the Wisconsin school of contract. ${ }^{23}$ As we now emphasize the binding nature of informal agreements, and do so with a view toward arrangements made within a business community, allowing for adaptations and amendments along the way, ${ }^{24}$ we recognize that to draw a line between the non-curtailed exercise of private power and a formalization and scrutiny of contracted rights might be just harder. It is here where we can already see the rise of current contentions about the primacy of social norms over law, the authors of which succeed so miraculously in blurring the relationship between both, eventually ridiculing law while depoliticizing social norms. ${ }^{25}$ Llewellyn stops short of further exploring the self-governing potential of informal arrangements, but takes an altogether hesitant approach to informal contracting, finding that it might introduce too much uncertainty into dynamic, fast-business dealings. ${ }^{26}$

Llewellyn's work stands in the context of that done, among others, by the economist and lawyer Robert Hale and the philosopher Morris Cohen. I shall briefly revisit the contentions made by these scholars with regard to contractual

22. Id. at $740-41$.

23. Stewart Macaulay, Non-Contractual Relations in Business: A Preliminary Study, 28 Ам. Soc. Rev. 55, 58-60 (1963); see also Christian Joerges, Status and Contract in Franchising Law, in FraNchising and the Law: Theoretical and Comparative Approaches in Europe and the United States 11, 22-23 (Christian Joerges ed., 1991) [hereinafter Franchising and the Law] (citing Stewart Macaulay, Long-Term Continuing Relations: The American Experience Regulating Dealerships and Franchises, in Franchising and the Law, id. at 179, 196).

24. Ian R. Macneil, The New Social Contract: An Inquiry into Modern Contractual Relations 26-27 (1980) (highlighting how planning is a process which continues after the contract has begun).

25. See, e.g., Eric A. Posner, Law and Social Norms 7-8 (2000). For a recent collection of scholarship discussing the nature and value of "social norms," see Norms aNd THE Law (John N. Drobak ed., 2006).

26. Llewellyn, supra note 3 , at $740-41$. 
governance as they-in concert with Llewellyn's observations--have much to tell us about the present challenges in "regulating contracts"--to borrow Hugh Collins's term. ${ }^{27}$

\section{Morris Cohen and "The Basis of Contract"}

While the latter half of the nineteenth century is settling to take Henry Sumner Maine's story of the shift from Status to Contract as the foundation for a liberal ideology of freedom of contract, ${ }^{28}$ Cohen seeks to uncover the blind spots in this story. ${ }^{29}$ Centrally, Cohen's astute critique contends that what happens when one contractual party prevails over the other is not merely the triumph of private power. Instead, the state vests the successful party with its own power, that is, the state's sovereignty. The private will of the parties does not decide a case. Rather, it is public policy that shapes and ultimately drives the contractual practice. In this context, contract law comes to be seen as being part of public law. "Enforcement, in fact, puts the machinery of the law in the service of one party against the other." ${ }^{130}$ Cohen observes that the amount of litigation refutes the principle agreed will is the base of contract law. ${ }^{31}$ Instead, in order to uncover the basis of contractual agreements and their enforceability, he inquires into the function currently carried out by contract law. He finds that the law of contract is partly

directed to strengthening the security of transactions by enabling men to rely more fully on promises [and partly about] the determination of the rights of the contracting parties as to contingencies that they have not foreseen, and for which they have not provided. ... [T] The law of contract is a way of enforcing some kind of distributive justice within the legal system. ${ }^{32}$

27. Hugh Collins, Regulating Contracts (1999).

28. See, e.g., Morton J. Horwitz, The Transformation of American Law 1870-1960: The Crisis of Legal Orthodoxy 33-63 (1992). For a description of how equitable concepts of contract law enforcement survived into the late eighteenth century, see Morton J. Horwitz, The Historical Foundations of Modern Contract Law, 87 HARv. L. Rev. 917, 920 (1974) ("[O]ne finds that as late as the eighteenth century contract law was still dominated by a title theory of exchange and damages were set under equitable doctrines that ultimately were to be rejected by modern contract law.").

29. Morris R. Cohen, The Basis of Contract, 46 HaRv. L. Rev. 553, 553-54 (1933).

30. Id. at 562 .

31. Id. at $576-77$.

32. Id. at 584 . 
Cohen lifts the ideological veil from the contractual exchange through which it had come to be interpreted as a transaction between rationally minded, sovereign market actors pursuing their own benefit with varying success through the creation of contractual rights and duties. Instead, as Cohen highlights, "the essential problem of the law of contract is the problem of distribution of risks." 33 Certainly, the identity of the institution that is implicated in this distribution is obscured by the liberal narrative of a freely contracting society, a narrative in which the role of the law is reduced to emphasizing, amplifying, and strengthening only that which the parties to the exchange had consented to out of free will. As is well known, Cohen rejects such "traditional individualistic theories" whereby law does but enforce the will of the parties, in other words, enforces that which the parties had agreed on. Cohen takes a closer look at the very moment when a court decides on a contract case before it and finds that parties will not seek resolution in the courts simply because they know what the line of the courts' reasoning is, has been, or is likely to be. In fact, the party that already found itself advantaged in the transaction can now call on the state to reinforce this advantage. The surprising outcome is that the private power turns into public power and vice versa.

The law of contract, then, through judges, sheriffs, or marshals puts the sovereign power of the state at the disposal of one party to be exercised over the other party. ... [T] he law of contract may be iewed as a subsidiary branch of public law, as a body of rules according to which the sovereign power of the state will be exercised as between the parties to a more or less voluntary transaction. ${ }^{34}$

The contracts made by powerful parties, standard contracts included, that are sanctioned by the state (or not invalidated), are nothing different than the bestowal of sovereign power on one party of the contract. This leads Cohen to observe that there would not be freedom without government providing the institutional framework of contract law. "Real or positive freedom depends upon opportunities supplied by institutions that involve legal regulation." ${ }^{.35}$

33. Id. at 584-85; accord Lon L. Fuller, Consideration and Form, 41 CoLum. L. Rev. 799, 799-800 (1941).

34. Cohen, supra note 29 , at 586.

35. Id. at 591 . 


\section{Robert Hale and the Supposedly Non-coercive State}

In many ways, this 1932 article by Morris Cohen spells out in greater detail and even more refinement the thesis he had already put forward in 1927, namely, that in order to understand the political and economic role of contract, we need to realize that in our concept of contract the public and private conceptions of sovereignty have collapsed. ${ }^{36}$ Cohen's succinct observation that the "legal term property denotes not material things but certain rights" ${ }^{\text {"37 }}$ echoes Robert Hale's analysis that where the government protects a property right, it regulates not the relation between man and thing but that between one person and other persons. ${ }^{38}$ That the law of property and contract serve to equip private actors with public power becomes obvious where we observe that coercion is coercion only where the law so recognizes. ${ }^{39}$ This of course bears strong relations to Hale's later work on duress and bargaining inequality, ${ }^{40}$ where he draws on Justice Holmes' deconstruction of the allegedly prima facie case of tortious conduct, based on the recognition of protected rights and their violation. ${ }^{41}$ In his famous 1923 article, Coercion and Distribution in a Supposedly Non-Coercive State, Hale not only strips the ideology of freedom of contract of its increasingly questionable cover, he also takes issue with laissez-faire's central contention that it is not government's purpose "to meddle consciously with the channels of industry ... .,42 $\mathrm{He}$ states the very inescapability of government intervention, not only in the moment where-for example, through court decisions or the issuing of express regulations and orders-the government openly intervenes, but, importantly, where it is not recognized to be intervening at all. The first form he illustrates thus: "government officials at various times have to make decisions as to the relative desirability of different chan-

36. Morris R. Cohen, Property and Sovereignty, 13 CoRNELL L.Q. 8, 11 (1928) (with reference to Justice Holmes' critique of the Supreme Court's endorsement of the laissez-faire doctrine, as evidenced in his dissent to the majority decision in Lochner v. New York, 198 U.S. 45 (1905), and to Roscoe Pound's refutation of the Supreme Court's elevation of the principle of freedom of contract into a property right).

37. Id. at $11-12$.

38. Robert L. Hale, Coercion and Distribution in a Supposedly Non-Coercive State, 38 Pol. Scr. Q. 470, 471-72 (1923).

39. Id. at 476; see Max Weber, ON Law in Economy and Society 188-91 (Max Rheinstein ed., Edward Shils \& Max Rheinstein trans., 1954).

40. Robert L. Hale, Bargaining, Duress and Economic Liberty, 43 Colum. L. Rev. 603 (1943).

41. Id. at 606-07 (with reference to Justice Holmes' dissent in Vegelahn v. Gunther, 167 Mass. 92 , 107 (1896)).

42. Hale, supra note 38 , at 491. 
nels of industry; and in making these decisions they can get no help from the market demands. ${ }^{, 43}$ The other form, the quiet, unnoticeable form of intervention, is one where the state, by means of property and contract law, quietly but no less powerfully upholds the unequal distribution of wealth and poverty in society, ${ }^{44} \mathrm{a}$ phenomenon indirectly reflected by the increasing expansion of the concept of duress during the late nineteenth century. ${ }^{45}$ The breathtaking conclusion of the article allows us to look deep into the abyss that opens when we look beneath the "principles of justice" that courts draw on when deciding property and contract cases. Hale convincingly argues that what courts are barely scratching at when they issue their judgments are the foundational distributive schemes existing in society. Hale shifts the focus away from judges to the greater political arrangement that sustains the economic order and points to the importance of politicizing the discussion of the issues that lie at the heart of such cases. Such a discussion, however, he contends, goes to the core of a democratic society and it is here where the discussion should take place. Hale's observation points to and beyond the obsession among legal thinkers and politicians with the role of judges in deliberating such conflicts and the endless quarrel over the political role of the judge, the limits of adjudication, and the need for judicial self-restraint. Hale shares with John Dawson the understanding that the courts can only take the first steps toward resolving societal issues, but cannot be the final arbiters, ${ }^{46}$ a finding that clearly resonates in contemporary discussions about the power of judges ${ }^{47}$ and the "neo-formalism" in the judicial interpretation of contractual agreements. ${ }^{48}$

43. Id.

44. See id. at 492-93.

45. John P. Dawson, Economic Duress-An Essay in Perspective, 45 Mich. L. Rev. 253, 265 (1947).

46. Id. at 289 ("It is evident that courts have neither the equipment nor the materials for resolving the basic conflicts of modern society over the distribution of the social product and the limits to be set to the use, or misuse, of economic power.").

47. E.g., David Campbell, The Incompleteness of Our Understanding of the Law and Economics of Relational Contract, 2004 Wis. L. Rev. 645, 650-54; Peer Zumbansen, Public Values, Private Contracts and the Colliding Worlds of Family and Market, 11 Feminist Legal Stud. 71 (2003).

48. E.g., Robert E. Scott, The Case for Formalism in Relational Contract, 94 Nw. U. L. Rev. 847, 848 (2000); see Richard Craswell, Contract Law, Default Rules, and the Philosophy of Promising, 88 Mich. L. Rev. 489, 489-90 (1989); Alan Schwartz, The Default Rule Paradigm and the Limits of Contract Law, 3 S. Cal. Interdisc. L.J. 389, 415-16 (1993). For a critique of this position, see Roy Kreitner, Fear of Contract, 2004 WIs. L. Rev. 429; Iain Ramsay, "Productive Disintegration" and the Law of Contract, 2004 Wis. L. Rev. 495 (2004). 


\section{Functionality of Contract I: The Welfare State and The Market Society}

\section{A. The Public-Private Challenge in Contract Law Theory}

The brief review of Legal Realist writing on property and contract has served to remind us of the alertness with which these scholars, writing at a crucial moment in Western industrial society, set out to attack a formalist understanding of law, which they saw as advantaging the already powerful over those who ideally should share the power in a modern, democratic society. ${ }^{49}$ Between Oliver Wendell Holmes Jr.'s Path of the Law, ${ }^{50}$ James M Landis' The Administrative Process, ${ }^{51}$ and the contract law writings by scholars such as Morris Cohen, Karl Llewellyn, and John Dawson, ${ }^{52}$ this work provided a succinct analysis of an increasingly regulated market society and government institutions. Their analysis uncovered the political content behind allegedly neutral assertions of individual rights, couched in a radical analysis of the interdependence of state and market in the regulation and exercise of contract and property. The development of contract law thinking, for which this small spotlight on Legal Realist and critical scholarship has marked the first step, is more interesting, as we will see that while for some time after World War II this critical inquiry continued to influence the debates over the role of contract law in the context of the regulatory state, it became increasingly less important or influential on the emerging mainstream as time went on..$^{53}$ Current contentions about the "death of contract law" 54 and fervent attacks on contract law adjudication ${ }^{55}$ seem strangely removed from the debates in the interwar and postwar periods. The timeliness of the Legal Realist analysis, however, in contexts not only of contemporary law reform in established legal orders but also in newly emerging states and transition markets, can hardly be overstated. Rights play a precarious role in the construction of a legal-political order, as they are deeply implicated in the creation and

49. For a discussion of the attack on freedom of contract, see Honwitz, supra note 28, at 33-63.

50. Oliver Wendell Holmes, Jr., The Path of the Law, 10 Harv. L. Rev. 457 (1897).

51. James M. Landis, The Administrative Process (1938).

52. E.g., Dawson, supra note 45.

53. See Charles Fried, Contract as Promise: A Theory of Contractual Obligation 2 (1981).

54. Robert E. Scott, The Death of Contract Law, 54 U. Toronto L.J. 369 (2004).

55. Posner, supra note 11. 
regulation of market relations ${ }^{56}$ through the direct redistributive effects on particular social positions that are either strengthened, weakened, or left untouched, thereby enforcing the status quo, but clearly never being "neutral."57

This perspective is of crucial importance in light of the fundamental shift from "government" to "governance" in administrative practice and theory. ${ }^{58}$ Against the background of dramatic changes in the organization and administration of public and private regulatory competences, ${ }^{59}$ the process by which rights are identified, protected, and exercised is again of the highest order. ${ }^{60}$ And yet, some factors suggest that a Legal Realist critique might no longer be possible in the same way that it was under conditions of the New Deal. In fact, current assessments of the post-regulatory state suggest the need for a much more differentiated perspective from which to study legal regulation of social relationships in complex contexts of mixed, publicprivate governance. ${ }^{61}$ Where the state itself must revisit its previous expansions into society, ${ }^{62}$ the critique of the legal means by which this regulation of society took

56. Duncan Kennedy, Three Globalizations of Law and Legal Thought: 1850-2000, in THE New Law and Economic Development 19, 19 (David M. Trubek \& Alvaro Santos eds., 2006) ("Legal institutions and ideas have a dynamic, or dialectical, or constitutive relationship to economic activity."); David M. Trubek, Max Weber on Law and the Rise of Capitalism, 1972 Wis. L. Rev. 720, 749.

57. See Kerry Rittich, The Future of Law and Development: Second Generation Reforms and the Incorporation of the Social, 26 Mich. J. INT'L L. 199, 211 (2004).

58. Orly Lobel, The Renew Deal: The Fall of Regulation and the Rise of Governance in Contemporary Legal Thought, 89 Minn. L. Rev. 342 (2004); Jody Freeman, Collaborative Governance in the Administrative State, 45 UCla L. Rev. 1 (1997); see also Gralf-Peter Calliess, Prozedurales Recht (1999); Peer Zumbansen, Ordnungsmuster im modernen Wohlfahrtsstaat. Lernerfahrungen zwischen Stant, Gesellschaft und Vertrag (2000); Peer Zumbansen, Quod Omnes Tangit: Globalization, Welfare Regimes and Entitlements, in The Welfare State, Globalization, and International Law 135 (Eyal Benvenisti \& Georg Nolte eds., 2004).

59. See, e.g., Alfred C. Aman Jr., Administrative Law and Process: Cases and Materials 27 (2nd ed. 2006) (describing the recently unfolding market-based approaches to regulatory governance); Michael Taggart, The Province of Administrative Law Determined?, in The Province of Administrative Law 1, 5-6 (Michael Taggart ed., 1997) (noting a remarkable negotiation between public and private law principles); Paul R. Verkuil, The Nondelegable Duty to Govern, in Governance by Design (Jody Freeman \& Martha Minow eds., forthcoming 2007) (manuscript on file with author) (questioning the viability of market ordering principles to solve public governance problems).

60. For a very telling critique of the "rights critique," see Duncan Kennedy, The Critique of Rights in Critical Legal Studies, in Left Legalism / Left Critique 178 (Wendy Brown \& Janet Halley eds., 2002).

61. See, e.g., Lobel, supra note 58, at 345-48.

62. Gunther Teubner, Juridification - Concepts, Aspects, Limits, Solutions, in Juridification of Social Spheres 3 (Gunther Teubner ed., 1987); Karl-Heinz Ladeur, Negative Freiheitsrechte 
place must confront the proliferation of regulatory forms by which the new state, which could be the neo-liberal enabling state ${ }^{63}$ or the empowering, learning enabling state, ${ }^{64}$ is switching from understanding itself as carrying out a task of societal regulation to learning its role in innumerable, complex, sensitive, and volatile processes of societal self-regulation. Yet, the availability of a dramatically enlarged toolkit in contemporary administrative governance ${ }^{65}$ is likely to make some critical jurists drowsy. Looking more closely at current contentions regarding the potential of private law regulation for public governance purposes, ${ }^{66}$ we soon recognize the need to remain skeptical toward this widespread enthusiasm for process and participation in administrative action. ${ }^{67}$ Lingering and lurching beneath the surface of the "new public governance ${ }^{\prime 68}$ are the same struggles over the way in which rights can be used in the fight over places in society. ${ }^{69} \mathrm{Clearly}$, we ought not to satisfy ourselves with substituting patterns of participatory governance for democratic government. ${ }^{70}$

\section{B. Is the Crisis of the Welfare State a Crisis of Contract Law?}

The previous section should have illustrated the degree to which contemporary discussions over governance by contract are inseparably caught up in ongoing delib-

und gesellschaftliche Selbstorganisation: Die Erzeugung von Sozialkapital durch InstiTUTIONEN (2000).

63. Kerry Rittich, Functionalism and Formalism: Their Latest Incarnations in Contemporary Development and Governance Debates, 55 U. Toronto L.J. [Special Issue] 853, 858 (2005).

64. Günter Frankenberg, Shifting Boundaries: The Private, the Public, and the Welfare State, in The Mixed Economy of Social Welfare 72, 93 (Michael B. Katz \& Christopher Sachße eds., 1996).

65. See Lester M. Salamon, The New Governance and the Tools of Public Action: An Introduction, 28 Fordham Ur B. L.J. 1611 (2001).

66. See generally Richard B. Stewart, Administrative Law in the Twenty-First Century, 78 N.Y.U. L. REv. 437 (2003) (detailing new methods, including actions by private actors, that have emerged to achieve the regulatory goals of the upcoming century).

67. See Benedict Kingsbury, Nico Krisch \& Richard B. Stewart, The Emergence of Global Administrative Law, 68 Law \& Contemp. Probs. 15, Summer/Autumn 2005, at 15, 56-57.

68. For analysis of the emergence of the welfare state, see Paul Pierson, The New Politics of the Welfare State, 48 World Pol. 143, 146-47 (1996); Thomas Wilhelmsson, Introduction to From Dissonance to Sense: Welfare State Expectations, Privatisation and Private Law 3, 4 (Thomas Wilhelmsson \& Samuli Hurri eds., 1999) [hereinafter From Dissonance to Sense] ("The state is the target of ideological attack, and on the surface level of concrete restructuring measures one encounters various methods of privatisation or marketisation....").

69. For an assessment of the democratic potential of administrative law, see Alfred C. Aman, Jr., Administrative Law for a New Century, in The Province of Administrative Law 90 (Michael Taggart ed., 1997).

70. See Stewart, supra note 66, at 460. 
erations over regulatory concepts in a complex regulatory environment. ${ }^{71}$ This observation is important as it underscores the connection between the public and private law discourse over regulatory governance. These discourses are intimately dependent on each other. The current regulatory environment is characterized by a high degree of uncertainty with regard to the political goals to be pursued, the means by which to pursue these goals, and the measurements of the instruments' success. With the Welfare state having become, again, ${ }^{72}$ a fighting term, the long and winding road toward achieving a balance between the tasks left to us by the American and French Revolutions, that is between freedom and equality, ${ }^{73}$ is currently being struck anew. While public lawyers are torn between embracing ${ }^{74}$ and critically exploring the suspiciously sweet promises of deliberative participatory regimes, ${ }^{75}$ private law theorists have been working away at the cathedral of private autonomy, declaring, again, ${ }^{76}$ a death of contract law ${ }^{77}$ and promoting a formalist approach to contractual governance. ${ }^{78}$ Such authors insist vehemently that both the state's incompetence to govern societal affairs effectively and the judiciary's alleged lack of expertise to govern contractual relations adequately ${ }^{79}$ provide sufficient evidence that private bargaining had better be left alone.

Striking in this assertion is its abstractness and insulation from the larger regulatory changes described earlier. The return to formalism is unfolding in a

71. See Lobel, supra note 58, at 362-63.

72. See, for example, the discussion of the New Deal critics in Daniel T. Rodgers, Atrantic Crossings: Social Politics in a Progressive Age 409 (1998), where Walter Shepard observed that the New Deal's ideology was "illogical, inconsistent, and turbid."

73. Alexis de Tocqueville, The Old Régime and the French Revolution 19-20 (Stuart Gilbert trans., 1955).

74. See, e.g., Michael C. Dorf \& Charles F. Sabel, A Constitution of Democratic Experimentalism, 98 Colum. L. Rev. 267 (1998).

75. For critical discussion on this issue, see Christoph Möllers, European Governance: Meaning and Value of a Concept, 43 Common Mkт. L. Rev. 313 (2006), and H.W. Arthurs, The Administrative State Goes to Market (and Cries 'Wee, Wee, Wee' All the Way Home), 55 U. Toronto L.J. 797 (2005). For the observation of the current American discussion, see Orly Lobel, The Paradox of Extralegal Activism: Critical Legal Consciousness and Transformative Politics, $120 \mathrm{H}_{\text {A Rv. L. Rev. } 938}$ (2007).

76. In a different vein, see P.S Atiyah, The Rise and Fall of Freedom of Contract (1979); Grant Gilmore, The Death of Contract (Ronald K.L. Collins ed., 2d ed.1995); Betty Mensch, Freedom of Contract as Ideology, 33 Stan. L. Rev. 753 (1981) (reviewing AtiYah, supra).

77. Scott, supra note 54, at 370.

78. See Schwartz \& Scott, supra note 6, at 543-46; Robert E. Scott \& George G. Triantis, Anticipating Litigation in Contract Design, 115 YALE L.J. 814, 878-79 (2006).

79. E.g., PosNer, supra note 25 , at 148-66; Scott, supra note 48 at $875-76$; Scott \& Triantis, supra note 78 , at $831-32$. 
troubling coincidence with a far-reaching transformation of public services and an increasing reliance by administrative agencies on market instruments in regulatory governance. ${ }^{80}$ Yet, instead of drawing the obvious conclusion to extrapolate the public content in the newly mobilized contractual designs of the contracting state, ${ }^{81}$ its new contract formalists rely exclusively on the competence and authority of bargaining parties to know "what is best for them" and argue, in turn, against any outside interference. ${ }^{82}$ Functionalism as the governing approach to public ordering constitutes the most successful contender in the struggle over regulatory concepts. But with the declining capability to regulate society effectively, the functionalist promise of progressive administrative governance ${ }^{83}$ is betrayed by its farcical return in the form of good market governance. ${ }^{84}$

Just as we can perceive a return of formalism in the public law discourse over regulatory governance, we see in current contract law discourses a striking insulation of contractual bargaining from the social relations that are shaped by contract. This insulation of contract rights from the political economy that is shaping them, and in which they are simultaneously implicated, is the more troubling as its success rests on the reintroduction of the public-private distinction, which we had believed we had productively overcome already a long time ago. The revival of the publicprivate divide and, with it, the alleged separation of a political and a non-political sphere of regulation occur without regard to the underlying struggles over the embedding political order and the way in which any meaningful discussion over rights must account for the larger regulatory and normative framework of which it is a part. As a result, this naiveté allows for a precarious repositioning of contractual governance. With increased reliance on private contract to enhance efficiency in market governance, defenders of judicial control of private arrangements are made

80. Jody Freeman has for many years now been an astute observer of these changes. See, e.g., Freeman, supra note 58; Jody Freeman, The Contracting State, 28 FlA. ST. U. L. Rev 155 (2000). For a discussion of the ubiquitous turn of public regulators to private market instruments, see Stewart, supra note 66.

81. See Freeman sources cited supra note 80 . For the perspective in the United Kingdom, see I AN Harden, The Contractinc State (1992). For the German perspective, see Peer Zumbansen, supra note 58; Peer Zumbansen, Vertragsregimes im "Dritten Sektor": Zur Verortung des Verwaltungsrechts angesichts des Zusammenwachsens privat und öffentlichrechtlicher Handlungsformen, in Non Profit Law Yearbook 61 (Rainer Walz et al. eds., 2003).

82. Robert E. Scott, Hoffmann v. Red Owl Stores and the Myth of Precontractual Reliance, 68 Oнго St. L. J. 71, 100-01 (2007) (“The emerging rule requires courts to resolve two key questions. When have the parties reached 'an agreement' sufficient to impose a duty to negotiate in good faith? And, what behavior constitutes a breach of that duty?").

83. See generally James M. Landis, The Administrative Process (1938).

84. Kerry Rittich, supra note 63 , at 856. 
to carry the argumentative burden of ensuring that the much-hoped for efficiency of private arrangements not be undone by policy-driven judicial intervention. Judges, in the new era of contract formalism, are allowed to intervene only in the most extreme cases, and arguably only with regard to party errors regarding form. ${ }^{85}$

The rejection of the Legal Realist critique that all rights, including those invoked by contracting parties, are policy is effective to the degree that the current embrace of formalism resonates with a far-reaching promotion of values of selfreliance, independence, and the "fear of state." 86 As a result, the triumph of individualism and autonomy conceals the de-politicization that characterizes the simultaneous occurrence of a far-reaching deconstruction of the welfare state and the rise of neo-liberal assertions of private autonomy ${ }^{87}$ Amidst a landslide of individualist doctrine, ${ }^{88}$ it has become increasingly difficult to point to the success of welfarist intervention —in itself contested ${ }^{89}$-into contractual governance. ${ }^{90}$ One of the reasons for the relatively fragile position of welfare contractualists is that there is no fully theorized or theorizable account of welfare state interventionism into contract law relations. ${ }^{91}$ Nor could there be, precisely because the distinction between the (self-regulating) market and the (intervening) state itself was always an artificial one. ${ }^{92}$ There was never a period of pure freedom of contract or of pure private autonomy. ${ }^{93}$ Instead, contractual bargaining regularly unfolded in the

85. Scott supra note 48, at 851 ; Posner, supra note 11. For a critique of judicial intervention in this context, see Duncan Kennedy, From the Will Theory to the Principle of Private Autonomy: Lon Fuller's 'Consideration and Form', 100 Colum. L. Rev. 94 (2000).

86. See Robert D. Putnam, Bowling Alone: The Collapse and Revival of American ComMUNITY (2000).

87. For a thoughtful discussion of this idea, see Daniela Caruso, Contract Law and Distribution in the Age of Welfare Reform, 49 Ariz. L. Rev. 665 (2007).

88. See, e.g., Schwartz \& Scott, supra note 6. For a critique, see Caruso, supra note 87.

89. Compare Posner, supra note 11 , with Zumbansen, supra note 47. For a position that allows for judicial intervention in tandem with changing welfare state politics, see Eric A. Posner, Contract Law in the Welfare State: $A$ Defense of the Unconscionability Doctrine, Usury Laws, and Related Limitations on the Freedom to Contract, 24 J. LeG. STud. 283 (1995).

90. See, e.g., Wilhelmsson, supra note 68, at 6 (arguing for a normative agenda of reforming private law in an era of globalization and privatization).

91. Collins, supra note 27; Zumbansen, supra note 58; Duncan Kennedy, Distributive and Paternalist Motives in Contract and Tort Law, with Special Reference to Compulsory Terms and Unequal Bargaining Power, 41 Mo L. Rev. 563 (1982).

92. Mensch, supra note 76, at 755 ("The classical ideal of free contract depended upon an abstract, and obviously unrealistic, model of contract formation. According to that model, only a voluntary exchange of promises (the traditional offer and acceptance) gave rise to contractual relations.").

93. For detailed analysis of this idea, see ZuMBansen, supra note 58, at 241-85. 
context of a certain regulatory framework. Mirroring this dilemmatic tension between formal freedom of contract and omnipresent, direct or indirect, administration of contractual relations, ${ }^{94}$ is the multifacetedness of legal fields such as economic law ${ }^{95}$ or social law, ${ }^{96}$ which reflects the foundational problems of distinguishing between public and private law. Such fields continue to challenge the doctrinal boundaries between, say, contract and corporate law, corporate and labor law, contract and social welfare law, and corporate and antitrust law. As such, however, the crossed boundaries, as well as the cross-boundary legal fields such as economic or social law, reflect on the ever recurring challenge for the law to express adequately the complexity of societal structures. ${ }^{97}$

\section{After Neutralization: The Contested Futures of Contract Law}

What, then, are the prospects of contractual governance-governance by and of contract-after the fading battle over state interventionism, welfarist contract law, and conflict and ideology in contract interpretation? As recently shown by Daniela Caruso, the retreat of the welfare state does not necessarily have to entail a judicial roll-back on controlling and invalidating unfair contract terms. Caruso ${ }^{98}$ finds evidence less of a full-blown defeat of the welfare state and welfarist contract theory ${ }^{99}$ than of a continued mixture of formalist and redistributive tendencies. ${ }^{100}$ Certainly, her suggestion is not to take the current attack on welfarist contract theory any less seriously. Instead, she argues for an exploration of the frictions that characterize the troubling alignments of welfare state reduction and formalism on the one hand and context-related fixtures and distributive decisionmaking on the other.

94. Duncan Kennedy, Form and Substance in Private Law Adjudication, 89 Harv. L. Rev. 1685, $1685-86$ (1976).

95. Christian Joerges, The Science of Private Law and the Nation State, in The Europeanization of Law: The Legal Effects of European Integration 47, 48 (Francis Snyder ed., 2000).

96. François Ewald, $A$ Concept of Social Law, in Dilemmas of Law in the Welfare State 40 , 40 (Gunther Teubner ed., 1986).

97. For an account of the emergence of these fields in the context of the interventionist state near the turn of the twentieth century, see Michael Stolleis, A History of Public Law in Germany 1914-1945, at 207-34 (Thomas Dunlop trans., 2004).

98. Caruso, supra note 87, with references to Poey v. Eggleston, 777 N.Y.S.2d 227 (N.Y. Civ. Ct. 2003) and Gavin W. v. YMCA of Metropolitan Los Angeles, 131 Cal. Rptr. 2 d 168 (Cal. Ct. App. 2003).

99. For an overview of welfarist contract theory, see Wilhemsson, supra note 68.

100. For comparative treatment, see Andreas Maurer, Consumer Protection and Social Models of Continental and Anglo-American Contract Law and the Transnational Outlook, 14 IND. J. GLobal Legal Stud. 353 (2007). 
The question is as to the sustainability of this perspective. At the moment, at least, contract formalists seem to have the wind in their sails when attacking judicial intervention, because the mere rhetoric of self-reliance, autonomy, and freedom of contract concurs with a much larger trend in current ideology. ${ }^{101}$ The endorsement of formalism and the rejection not of contract, but of contract law, unfolds at a critical time for any attempt at re-politicizing legal regulation. In short, any revitalization of a political or critical theory of contract, grounded in a Legal Realist critique of rights as ideology, ${ }^{102}$ is facing circumstances under which the identification and definition of the political, of its institutional framework and normative dimensions themselves, have become highly contested. The intricate transformation of state sovereignty in an era of globalization, its erosion from above through internationalization $^{103}$ and from below through privatization and deregulation, ${ }^{104}$ presents a particular challenge for reformist politics, which gets entangled in complex negotiations over levels and sites of policymaking. ${ }^{105}$ Expanding the view from the domestic welfare state to larger trends in public regulation repositions contractualization of local politics within a globally traceable movement from "government to governance." ${ }^{106}$ Against this background, the turn to contract can be studied as a farreaching phenomenon that is not confined to the nation state. Like other changes in regulatory practice, theory, and discourse, they are shaped and influenced through a fundamentally de-nationalized, transnational process, ${ }^{107}$ which has prompted, on one end of the debate, an embrace of legal pluralism and societal law ${ }^{108}$ and, on the other, ardent defenses of state sovereignty. ${ }^{109}$

101. See Posner, supra note 11.

102. Kennedy, supra note 60, at 201; Mensch, supra note 76.

103. Saskia Sassen, Globalization or Denationalization?, 10 Rev. INT'L Pol. Econ. 1 (2003).

104. Alfred C. Aman, Jr., The Democracy Deficit 88-89 (2004); Aman, supra note 69, at 90.

105. For a comprehensive discussion of this issue, see Dorf \& Sabel, supra note 74, and Oliver Gerstenberg, Justification (and Justifiability) of Private Law in a Polycontextural World, 9 Soc. \& Legal Stud. 419 (2000).

106. Alfred C. Aman, Jr., The Limits of Globalization and the Future of Administrative Law: From Government to Governance, 8 Ind. J. Global Legal Stud. 379, 379 (2001) ("One of the hallmarks of regulation in the global era has been the shift from state-centered, command-control approaches to market forms of regulation.") (citations omitted).

107. Harold Hongju Koh, Transnational Legal Process, 75 Neb. L. Rev. 181, 183-84 (1996).

108. Gunther Teubner, 'Global Bukowina': Legal Pluralism in the World Society, in Global Law Without A STAte 3 (Gunther Teubner ed., 1997). For a recent elaboration, see Ralf Michaels, The Re-state-ment of Non-State Law: The State, Choice of Law, and the Challenge from Global Legal Pluralism, 51 WAyn L. Rev. 1209 (2005); Ralf Michaels, The True Lex Mercatoria: Law Beyond the State, 14 Ind. J. Global Legal Stud. 447 (2007).

109. For the most striking contribution in this regard, see Goldsmith \& Posner, supra note 7. 
It seems to follow from this perspective that when making a Legal Realist critique of these developments, their new, transnationalized nature might escape an understanding of the political, which remains centered on local, nation-state oriented institutions and processes. ${ }^{110}$ In other words, how reliable is a critique that points to the political underpinnings of a formalist approach in order to reintegrate contractual governance into a larger framework of political (legal) theory ${ }^{111}$ under circumstances in which the sites of democratic politics have become de-centered, fragmented, ${ }^{112}$ and denationalized ${ }^{1113}$ Can such an approach to distributive issues in contractual governance be adequate in light of ongoing, dramatic transformations of public and private regulatory functions that ultimately illustrate a need to reconceptualize political theory? ${ }^{114}$ Where the Legal Realists were still able to turn their critique of state and market power into a progressive agenda of balancing the public and the private, ${ }^{115}$ we are facing a much more difficult task in identifying first of all our yardstick by which to measure societal power in a society characterized by a paradoxical erosion of the public-private divide, ${ }^{116}$ enabled by an ever increasing heterarchy of societal visions and identities. ${ }^{17}$ What are the criteria by which we shall identify, discuss, and address the dimensions of contractual relations?

110. Joerges, supra note 95, at 47-48; see also Jürgen HABERMas, The New Obscurity: The Crisis of the Welfare State and the Exhaustion of Utopian Energies, in Jürgen Habermas, The New Conservatism: Cultural Criticism and the Historians' Debate 48, 65-66 (Shierry Weber Nicholsen ed. \& trans., 1989) ("The state administration not only structures but largely controls the legislative process....").

111. See, e.g., Arthur Ripstein, Private Order and Public Justice: Kant and Rawls, 92 VA. L. Rev. 1391, 1392 (2006), ("Private rights protect an important kind of freedom. They are not simply bestowed on citizens by the state so as to increase prosperity or provide incentives. At the same time, their enforcement is an exercise of political power, for which society as a whole must take responsibility.").

112. See generally Martti Koskenniemi \& Päivi Leino, Fragmentation of International Law? Postmodern Anxieties, 15 LEIDEN J. INT'L L. 553 (2002) (discussing the concern that the proliferation of international tribunals is exacerbating the fragmentation of international law).

113. See generally Sassen, supra note 103 (discussing particular conditions that make execution of the state's role in the process of denationalization today different than it was in the past).

114. For a discussion of these challenges, see James Tully, Strange Multiplicity: Constitutionalism in an Age of Diversity (1995).

115. Cohen, supra note 36 , at 8; Hale, supra note 38 , at 478.

116. For a forebearer, see Roscoe Pound, The New Feudalism, 16 A.B.A. J. 553, 554-55 (1930).

117. Lobel, supra note 58 , at 343-45. 


\section{Troubling Alliances}

At this point, we can see a surprising convergence of purportedly distinct theoretical approaches. All of the above described approaches have one perspective in common: their starting point is no longer only the state and a legal regime of contractual governance deeply embedded in a particular political economy and its domestic regulatory framework. Instead, contractual governance is believed to occur at the level of society. In that respect, law and society scholars share as much with theorists of reflexive law and systems theory as they do with $L \& E$ protagonists. To emphasize, for example, the role of social norms in shaping pre-contractual agreements, rather than the focus of judicial intervention on contractual relations, establishes a peculiar proximity between $L \& E$ scholars' recent discovery of "social norms" 118 and a rejection of contract law on the one hand and different concepts of societal self-rule, ranging from legal pluralism ${ }^{119}$ to democratic experimentalism, ${ }^{120}$ on the other. This variety of dimensions inherent to contractual thinking suggests that contract remains a most promising concept for social theory. From this perspective, contract continues to occupy a central place in the imaginary and conceptual realm of disciplines including history, ${ }^{121}$ economics, ${ }^{122}$ anthropology, ${ }^{123}$ and law.

With a view to the paradoxical, seeming proximity between conservative and progressive approaches to contract law in their shared interest in embedding contract in societal practice, however, the current prevalence of formalism as it has been mobilized against welfarist and intervenionist contract theories seems to tilt

118. For a critique of the de-politizing reliance on social norms by law and economics scholars, see Robert C. Ellickson, Law and Economics Discovers Social Norms, 27 J. Leg. STud. 537 (1998).

119. Sally Engle Merry, Anthropology, Law, and Transnational Processes, 21 Ann. Rev. AntrroPolocy 357, 357-59 (1992); Sally Engle Merry, Legal Pluralism, 22 Law \& Soc'y Rev. 869 (1988); see Gunther Teubner, The King's Many Bodies: The Self-Deconstruction of Law's Hierarchy, 31 Law \& Soc'y Rev. 763, 763-66 (1997).

120. Dorf \& Sabel, supra note 74.

121. See, e.g., Henry Sumner Maine, Ancient Law: Its Connection with the Early History of Society and Its Relation to Modern Ideas (Beacon Press 1963) (1861) (famously describing the move from archaic through tribal to modern societies, constituting a "movement from status to contract"); Horwitz, supra note 28.

122. See, e.g., Oliver E. Williamson, The Lens of Contract: Private Ordering, 92 Ам. Econ. Rev. (Papers \& Proc.) 438 (2002); Oliver Hart \& John Moore, Contracts as Reference Points (Nat'l Bureau of Econ. Research, Working Paper No. 12706, 2006), available at http://www.nber.org/papers/ w12706.

123. See, e.g., Sally Falk Moore, Law and Social Change: The Semi-Autonomous Field as an Appropriate Subject of Study, 7 Law \& Soc'v Rev. 719, 723-29 (1973). 
the balance to one side. As emancipatory approaches increasingly become confined to the area of social and cultural studies, the L\&E adherents within the legal academy and the judiciary seem to be gaining more and more ground in a discourse that seems increasingly dominated by concerns of efficiency, competitiveness, and private ordering. As contracts become reduced to mere instruments in advancing economic development ${ }^{124}$ and integration, ${ }^{125}$ it becomes increasingly difficult to conceptualize or even to elaborate on a coherent strategy of addressing the redistributive elements, the normative underpinnings, of contractual design.

\section{Functionality of Contract II: Law and Economics Discover Social Norms}

While the relationship between law and social norms has long been the subject of intense scholarly debate, ${ }^{126}$ recent contributions of $L \& E$ scholars have given the discussion a particular twist. ${ }^{127}$ In the context of an increasingly complex regulatory environment of public and private, domestic and transnational "norm entrepreneurs," ${ }^{128}$ social norms are perceived as efficient rules, developed by "many specialized business communities" to govern social behavior. ${ }^{129}$ Social norms bear particular importance for L\&E scholars in that they are being studied with regard to the possible reasons of their moving toward efficiency. ${ }^{130}$ This constitutes a novel interest in social norms when compared to the interest of $L \& E$ scholars in institutions of formal law. ${ }^{131}$ Robert Ellickson, one of the leading scholars of private ordering, ${ }^{132}$ has

124. See Richard A. Posner, Creating a Legal Framework for Economic Development, 13 Workd Bank Res. Observer 1, 1-3 (1998).

125. For a recent critique of a neutralized conception of European Contract Law, see Ugo Mattei \& Fernanda Nicola, $A$ "Social Dimension" in European Private Law? The Call for Setting a Progressive Agenda, 41 New ENGL. L. Rev. 1 (2006).

126. For a brilliant introduction to the issues and the literature, see Pierre Bourdieu, The Force of Law: Toward a Sociology of the Juridical Field, 38 Hastings L.J. 814 (1987); Moore, supra note 123; Teubner, supra note 62.

127. See, e.g., Posner, supra note 25; Richard A. Posner, Social Norms, Social Meaning, and Economic Analysis of Law: A Comment, 27 J. Legal Stud. 553 (1998). For a critique of this idea, see Ellickson, supra note 118.

128. Cass R. Sunstein, Social Norms and Social Roles, 96 Colum. L. Rev. 903, 909 (1996).

129. Robert Cooter \& Thomas Ulen, Law \& Economics 439 (4th ed. 2004).

130. Id. at $439-440$.

131. For examples of the interest in institutions of formal law, see R.H. Coase, The Problem of Social Cost, 3 J.L. \& Econ. 1, 1-2 (1960); Ellickson, supra note 118, at 540.

132. See, e.g., Robert C. Ellickson, Order Without Law: How Neighbors Settre Disputes (1991). 
placed this renewed interest among $L \& E$ scholars in social norms in the context of "many disciplines increasingly ... emphasizing the significance of the informal glue that holds a society together." ${ }^{\text {"33 }}$ While sociologists' research on norms had for a long time failed to exert significant influence on other fields, perhaps because of the field's preoccupation with groups as "operative agents" and L\&E scholars' respective focus on "methodological individualism," 134 obviously much has come into motion recently. ${ }^{135}$ At the same time, there remains much dispute within L\&E as to the primacy of either law or social norms. ${ }^{136}$

This current soul-searching is important for our present inquiry because it illustrates the contentious relationship between formal and informal law, an understanding of which is central to present studies of contemporary lawmaking developments in different areas of law, ${ }^{137}$ and because it is a case in point for our present study of contractual governance. The present debate strikingly reemphasizes the distinction between cooperative and regulatory functions of norms, a distinction that should arguably be overcome in the conceptualization of a hybrid governance regime, assuming it ought to carry out both functions. ${ }^{138}$ In contrast, recent L\&E scholars seem clearly to favor social norms to govern cooperative behavior among social actors, while attributing at best an ambivalent role to the state not only in channeling these private norms, but also in effectively intervening into problematic social relations.

133. Ellickson, supra note 118, at 541.

134. Id. at 542; see also Robert D. Cooter, Against Legal Centrism, 81 CAL. L. Rev. 417, 426 (1993) (reviewing Ellickson, supra note 132) ("Of course, sociology is not an unqualified improvement over abstract economic theory.").

135. Ellickson, supra note 118, at 543 (noting that in the mid-1990s, norms had become "one of the hottest topics in the legal academy). For additional sources illustrating this point, see Rules AND Networks: The Legal Culture of Global. Business Transactions (Richard P. Appelbaum, William L.F. Felstiner \& Volkmar Gessner eds., 2001); Ellickson, supra, at 543 nn. 22-24; Symposium, Law, Economics, and Norms, 144 U. PA. L. Rev. 1643 (1996).

136. Ellickson, supra note 118, at 551-52.

137. See, e.g., Gralf-Peter Calliess, Reflexive Transnational Law. The Privatisation of Civil Law and the Civilisation of Private Law, 23 Zeitschrift für Rechtssoziologie 185 (2002) (discussing the emergence of transnational private law in alternative dispute resolution bodies); Simon Deakin, The Many Futures of the Contract of Employment, in Labour Law in an Era of Globalization: Transformative Practices and Possibilities 177 (Joanne Conaghan et al. eds., 2002); Snyder, supra note 10; Peer Zumbansen, The Parallel Worlds of Corporate Governance and Labor Law, 13 Ind. J. Global Legal Stud. 261 (2006); Peer Zumbansen, The Privatization of Corporate Law? Corporate Governance Codes and Commercial Self-Regulation, Juridikum 136 (2002).

138. This section builds on the research project by Gralf-Peter Calliess \& Peer Zumbansen, Rough Consensus and Running Code: A Theory of Transnational Private Law (Univ. of Bremen, TransState Working Paper 2007). 
Eric Posner, in a powerful reformulation of L\&E's position on "law and social norms," recently underlined how the latter provide an efficient regulatory tool, ${ }^{139}$ particularly in light of the continuously rising costs of invoking the state legal system. Posner emphasizes that even in contract law relationships, parties will not try to breach their agreements with each other because they fear the other's invocation of the legal system. Rather, he believes that where parties rely on the court to resolve conflicts they incur substantial risks as courts are bound to misunderstand the existing practices in contemporary commercial relations. Not only do parties here abstain from (over-) burdening courts, which they anyway hold to be incompetent, ${ }^{140}$ but they forcefully rely on the parties' willingness to engage with the other in a way that is efficient for both sides, involving "reputation, ethnic and family connections, and other elements of nonlegal regulation." "141 "[T] he chance of winning a breach of contract suit is pretty much random." 142

It has already been alluded to that some angles of this analysis of course build on much older, but also differently situated, work on the role of informal agreements in the area of contractual relations, most significantly elaborated on by scholars such as Stewart Macaulay and Ian Macneil. ${ }^{143}$ Their work on relational contracts, intricately situated between contract and organization, and on private government, has laid the groundwork for ensuing research into organizational patterns that overcome the classical, one-off focus of contractual agreements ${ }^{144}$ to provide a framework for adaptive governance and flexible relational design ${ }^{145}$ It is important to accept that such governance regimes are neither purely private nor public in nature. ${ }^{146}$

139. Posner, supra note 25 , at $148-150$.

140. Id. at 152. ("Courts have trouble understanding the simplest of business relationships.").

141. Id. at 153.

142. Id.

143. E.g., Macaulay, supra note 23; Ian R. Macneil, Relational Contract: What We Do and What We Do Not Know, 1985 Wisc. L. Rev. 483.

144. David Campbell, Ian Macneil and the Relational Theory of Contract, in The Relational Theory of Contract: Selected Works of Ian Macneil 3 (David Campbell ed., 2001); David Campbell, The Relational Constitution of Contract and the Limits of "Economics": Kenneth Arrow on the Social Background of Markets, in Contracts, Co-operation, and Competition: Studies in Economics, Management and Law 307 (Simon Deakin \& Jonathan Michie eds., 1997); John P. Esser, Institutionalizing Industry: The Changing Forms for Contract, Law \& Soc. INQ. 593 (1996); Lobel, supra note 58, at 383 (emphasizing how the use of relational agreements between bureaucracies and citizens strengthens the interface between both).

145. See Freeman, The Contracting State, supra note 80, at 171 ("[T] work and a set of default rules that will help direct future gap filling.").

146. Salamon, supra note 65, at 1613; see also Carol Harlow, "Public" and "Private" Law: Definition Without Distinction, 43 Mod. L. Rev. 241, 249-50 (1980) ("The intervention of a static 'public/pri- 
Against the background of these advances in contract and administrative law thinking, ${ }^{147}$ the current reiterations among $\mathrm{L} \& \mathrm{E}$ scholars suggesting that social norms are determinative of contractual relations are problematic because they are insulated from the discussion among administrative law scholars and relational contract theorists as to the public and, with that, the political content of the new hybrid regimes. The $L \& E$ scholars' interest in social norms is driven by a determination to keep contractual governance free of politics. Their interest in social norms is not in the societal basis of norm-making as part of a larger exploration of sites of political will formation, but reflect instead their intention to privatize, formalize, and de-politicize the complex phenomena of contemporary regulatory governance.

Driven by these goals, these scholars are critical of judges' alleged incompetence. The result of their claim of the irrelevance of contract law is that the latter is removed from political negotiation. As such, the endorsement of social norms by $L \& E$ scholars ${ }^{148}$ effectively removes contract law from a longstanding development of conflict negotiation, for which contract law provides a most powerful framework..$^{199}$ As scholars such as Eric Posner, Robert Scott, and Alan Schwartz argue in favor of a re-formalization of contract law in order to free it from judicial activism (and incompetence), we can begin to discern the rationale that underlies their renewed interest in social norms. Where they dream of a purified law of contract, cleansed of uncontrollable redistribution policies that judges pursue through doctrines such as unconscionability or duress, we must search for the deeper motivation of their implied rejection of much of contract law's development in the twentieth century. Against the background of contract law, which, in the historical context of the welfare state, had increasingly assumed regulatory

vate' classification can only hinder this development by blinding us to obvious parallels and encouraging uneven growth.").

147. For further discussion on this topic, see Harm Schepel, The Constitution of Private Governance. Product Standards in the Regulation of Integrating Markets 259-284 (2005) (examining the recent developments in U.S. administrative law and the changing features of the non-delegation doctrine), and Verkuil, supra note 59 (endorsing a circumscribed role for privatization, but arguing against delegation of policy functions to private actors).

148. Posner, supra note 25, at 154.

149. Cf. Roy Kreitner, Frameworks of Cooperation: Competing, Conflicting, and Joined Interests in Contract and Its Surroundings, 6 Theoretical I nquiries L. 59, 111 (2005) (“The conflicts of interest perspective I have proposed here challenges economic thinking to compare things whose comparison is difficult, with tools that do not promise precision. At the same time, it attempts to expand the set of tools to make such comparisons. The conflicts of interest perspective may run aground trying to account instrumentally for things whose value lies beyond instrumentality, but one may hope that the failure would be enlightening."). 
functions toward redistribution, ${ }^{150}$ the suggested return to a formal contract law regime, through a literal interpretation under very restricted circumstances and accompanied and supplemented by a system of social norms, which themselves operate through signaling and reputation, turns out to be a well-known version of a particular understanding of private law: that which the Legal Realists identified in the 1920s as inadequate and misleading representations of the law governing contemporary market relations. ${ }^{151}$ L\&E's new interest in social norms then appears to be but a new attempt to reestablish a private, purified, and neutral system of private law, uninhibited by activist judges, consumer protection lobbyists, and ideas of constitutional contractual governance. ${ }^{152}$ Central is the authors' distinction between an allegedly neutral private law arena (the market) and a value-laden, political realm (the state).

In a recent contribution to the $\mathrm{L} \& \mathrm{E}$ scholarship on regulatory competition in corporate law, Professors Gillian Hadfield and Eric Talley suggest that where the law is to perform economic functions, the state might not be optimally suited to assume that role. ${ }^{153}$ This finding builds on an earlier observation, namely that it would be a mistake "to equate competition among political bodies or courts with competition among profit-maximizing firms. Politicians and bureaucrats do not evaluate and pursue innovations in law in the way that entrepreneurs do-with the speed, flexibility, resources, and incentives of the market at their disposal." 154

As becomes apparent, the distinction between economic and non-economic functions of law is central to Professors Hadfield and Talley's understanding of the regulation through law as such. In her famous paper on Privatizing Commercial Law, Professor Hadfield posited the potential of a "truly competitive private legal regime" as "one in which entities design and implement the substantive and the procedural rules with an eye to market incentives, market rewards, and market penalties." 155 This proposal followed from her answer to the question on the privatization of law: "Should the economic services aspects of law also be delivered

150. See Zumbansen, supra note 58, at ch. c.; Anthony T. Kronman, Contract Law and Distributive Justice, 89 Y ALE L.J. 472, 472-74 (1980).

151. See, e.g., Cohen, supra note 36; Hale, supra note 38.

152. See Zumbansen, supra note 47 , at 72 .

153. Gillian Hadfield \& Eric Talley, On Public Versus Private Provision of Corporate Law, 22 J.L. Econ. \& Org. 414, 415 (2006); see also Gillian K. Hadfield, Privatizing Commercial Law, ReculaTION, Spring 2001, at 40, 40 ("[T] he legal system also performs important economic functions such as providing the structure and regulation necessary for the operation of efficient markets.").

154. Hadfield, supra note 153 , at 41 ; see also Hadfield \& Talley, supra note 153 , at 416.

155. Hadfield, supra note 153 , at 41. 
through the market, or must they be delivered by the state?"156 This question itself is in need of a motivating background, one that she readily provides by putting forward the very distinction that, in her recent paper with Professor Talley, lays the foundation of their thesis: "the provision of corporate law by profit-maximizing firms can achieve greater efficiency than when corporate law is provided by public entities. In the static one-shot case, private entities offer differentiated regimes for heterogeneous population of incorporating firms, which is closer to the first-best than the emulation exhibited by public regulators." 157 This thesis rests on the fundamental distinction between what Professors Hadfield and Talley refer to as the "justice" and the "economic" functions of law. ${ }^{158}$ This distinction is so crucial to their proposal of a regulatory private legal regime that it deserves to be reproduced here in greater detail:

The democratic functions of law-those that involve the fundamental social contract between the governed and the government-are provided almost exclusively by state actors: public courts and legislatures established and regulated in turn by constitutional documents or principles. Most notions of democratic legitimacy virtually require that the state play this role. Indeed, a basic principle of democracy is that the state may exercise power and may only exercise power vis-à-vis the governed through institutions that are accountable, ultimately, to the polity.

What is less clear, however, is why the economic functions of law-the market structuring functions-are produced by the state. Why does the state assume responsibility for designing the structure of the relationships within and between economic entities when the instrumental objective is not democratic legitimacy, but rather market efficiency? Law in its economic function is largely a service. It enhances the value of transactions; it coordinates activities, provides a means of commitment, and resolves disputes in the cooperative endeavors that characterize economic activity. The optimal provision of law in these functions means the

156. Gillian K. Hadfield, Privatizing Commercial Law: Lessons From ICANN, 6 J. SMall \& Emerging Bus. L. 257, 263 (2002).

157. Hadfield \& Talley, supra note 153, at 436.

158. Id. at 415 . 
efficient design and implementation of the rules that structure and regulate the market economy. ${ }^{159}$

In her earlier article, Professor Hadfield emphasized that "[b]ecause the justice sphere of the legal system involves the rights and obligations of citizens, it must be delivered by the state for reasons of democratic legitimacy." 160 The underlying distinction between what the state can do on the one hand and what the market ought to do, on the other, by which Professors Hadfield and Talley distinguish between the "justice" and the "economic" functions of the law, could otherwise be identified as the regulative and coordinative functions of the law. ${ }^{161}$ While it could be argued that the distinction of these dimensions of the law goes a long way toward a disentanglement of institutions (public and private) and norms (hard and soft, official and unofficial) and thereby could be seen to contribute, for example, to a more adequate description of the complexity of regulatory competition, which would encompass the collision of values, institutions, and different forms of capitalist political economies, ${ }^{162}$ much remains unanswered. Central here is the question how to differentiate between the justice and the economic functions. Much suggests that the distinction begs the very question of what can be understood as "regulation through law" to begin with. Professors Hadfield and Talley associate the welfare enhancing, third-party protecting, and rights-granting capacities of the law with the institution of the state. The state alone, in their eyes, can safeguard and deliver the legitimate and accountable exercise of public authority. The state, in their depiction, is positioned in clear opposition to other entities that are purportedly more apt to provide those institutional and normative instruments that are needed by market actors. While this picture is informed by references, for example, to structures of private ordering in medieval times, ${ }^{163}$ its underlying separation of public and private ordering rests on a crude reductionism with regard to the functions that are assumed by the "state" in comparison with those allegedly delivered by the "market." Such a distinction appears unconvincing for a number of reasons. The portrait of an un-

159. Id.

160. Hadfield, supra note 153 , at 40.

161. Calliess \& Zumbansen, supra note 138. For an application of this distinction in the area of technical standard setting, see Raymund Werle \& Eric J. Iversen, Promoting Legitimacy in Technical Standardization, Sci. Tech. \& Innovation Srud., March 2006, at 19, $21-22$.

162. See, e.g., Colin Crouch, Models of Capitalism, 10 New Pol. Econ. 439 (2005) (discussing diverse forms of capitalist economies). For a description of such a political economy model of regulatory competition, see Peer Zumbansen, Spaces and Places: A Systems Theory Approach to Regulatory Competition in European Company Law, 12 Eur. L.J. 534 (2006).

163. Hadfield, supra note 153 , at 41-42. 
political market falls back before the critique of market relations and property rights developed by Morris Cohen and Robert Hale in the 1920 s. ${ }^{164}$ It also fails to acknowledge the manifold transformations of private contract law through adjudication in the name of public welfare and various distributive rationales. The pure private law that is assumed by Professors Hadfield and Talley is not the one we have been studying in advanced Western states in the twentieth century. Their contention of a clear divide between the state and the market overdraws the institution of the state, which is presented as a closed entity that follows merely a confined set of rules. The state has long been analyzed as merely a chiffre for a historically contingent form of concentrating and exercising political power. But, like the forms in which political power has come to be exercised in an increasingly complex and heterogeneous society, the state itself has undergone dramatic changes. Today, the debates have already begun to go beyond the discussion over the retreat or the return of the state, and instead have started to study the state from different perspectives of social ordering. Despite their keen interest in the regulatory framework of commercial and corporate lawmaking, Professors Hadfield and Talley appear to hold on to a model of state and society that, in the end, makes it difficult to envision the various, complex forms of public and private, cooperative and regulatory functions that are assumed by hybrid normative regimes today. In light of the multifarious challenges facing any regulatory entity today, a model which conceptually builds on an allegedly clearcut separation of justice and economic functions falls short of capturing the nature of regulatory governance. As has been shown repeatedly by administrative law scholars and experts in regulatory theory, ${ }^{165}$ to build on the distinction of public and private elements of governance in order to identify the proper regulatory agents and their purported competences might miss the specific governance challenges arising from human interaction and societal transactions in complex, multilateral contexts. $^{166}$

These foregoing findings make the current work by L\&E scholars on law and social norms, as well as on regulatory competition, an ill fit for our inquiry into the role and potential of contract law in present society. With its reiteration of the well-known separation between an allegedly neutral private law and a value-

164. See Cohen, supra note 36; Hale, supra note 38.

165. E.g., Aman, supra note 69; Freeman, supra note 58; Lobel, supra note 58; Richard B. Stewart, The Reformation of American Administrative Law, 88 Harv. L. Rev. 1667 (1975).

166. See generally Robert Wai, Transnational Private Law and Private Ordering in Contested Global

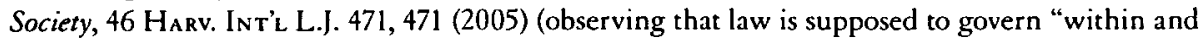
between social systems, including through allowing and sometimes facilitating conflict and constestation"). 
laden, political public law, L\&E's current interest in law and social norms might not have much to offer for an understanding of normative regimes, which distinctively combine, merge, and fuse elements of public and private law. By contrast, our focus needs to be continuously directed toward those areas of societal activity where contractual arrangements are being resorted to in search of a highly sensitive, flexible, and organizational paradigm. The interaction between formal and informal rules must be understood as one of false opposites. Whether a norm is public or private or formal or informal in nature becomes a question of societal practice, evidenced through the law's evolutionary selection of categories and instruments by which conflicts are being legalized. Where Luhmann observed that, perhaps, the concept of (the rule of) law might after all have been merely a European anomaly and there might not be an equivalent in a globalized world, ${ }^{167}$ we are tempted to seek out ways of seeing formal and informal laws interpenetrating in the illustration, exposition, and realization of conflicting rationalities, values, and heritages.

\section{Contract Law in a Fragmented Society}

\section{A. The Loss of the Political?}

Whether it be in the context of law reform ${ }^{168}$ or legal harmonization, as in the case of European Private Law, ${ }^{169}$ the place of contract law and, with that, the place of policy inquiry into its basis and effects, has become harder to determine. Contract law, in both cases, seems to have been reduced to merely one element among many in a more general law reform process stressing the values of private autonomy and the limits of state action in regulating social affairs. However, where the political nature of that process, its goals and aspirations, remain contested, this has effects on the normative framework of each of its legal elements as well. Just as doubts about the many unanswered questions regarding the political stakes of corporate law in law reform in transition markets continue to linger, ${ }^{170}$ the process of multilevel law-

167. Niklas Luhmann, Law as a Social System 484-88 (Fatima Kastner et al. eds., Klaus A. Ziegert trans., 2004).

168. E.g., Rittich, supra note 57, at 204-205.

169. E.g., Mattei \& Nicola, supra note 125, at 12.

170. Zumbansen, supra note 137, at 261-65; Peer Zumbansen \& Patrick Rundans, The Political Economy of Legal Transplants: The Case of Corporate Law, in The Political Economy of Corporate Governance (Peer Zumbansen \& John W. Cioffi eds., forthcoming 2007) (manuscript on file with author). 
making and the resulting inconsistencies and fragmentations of legal bodies, as evidenced in the European context, ${ }^{171}$ illustrate the importance of rediscovering that which is at stake in lawmaking in these contexts. It is here where the emergence of myriad forms of soft law making, as can be observed in the proliferation of codes of conduct and best practice guidelines in law reform contexts ${ }^{172}$ and in European lawmaking, ${ }^{173}$ further complicates the legal field. The legal field is semi-autonomous in that it is made up of co-existing and intertwining formal and informal norms. ${ }^{174}$ This makes it important to focus on the particular tension arising between the two spheres of the legal field in order to trace the generation and legitimacy of norms. The choice of legal instruments is currently regularly characterized as a merely technical question under constraints of efficiency. ${ }^{175}$ Instead, the reliance on soft or hard, on direct or indirect forms of regulation rests on policy choices and is, as such, inseparable from underlying negotiations over social relationships and redistributive decisions. ${ }^{176}$ At the same time, as we have seen, the evolution of regulatory discourse in an increasingly transnational and heterogeneous context leads to a widening and disintegration of underlying policies. ${ }^{177}$ As a consequence, the legal theory and critique of regulatory instruments must be adapted to these new circumstances.

171. See generally Mattei \& Nicola, supra note 125 (discussing the Europeanization of private law).

172. Kerry Rittich, Recharacterizing Restructuring: Law, Distribution and Gender in MARKET ReFORM (2002).

173. E.g., Simon Deakin, Paper Presentation at the European Corporate Governance Forum, University College, Dublin: Reflexive Governance and the European Corporation (Jan. 19, 2007) (on file with author); see also David M. Trubek \& Louise G. Trubek, Hard and Soft Law in the Construction of Social Europe: The Role of the Open Method of Co-ordination, 11 Eur. L.J. 343 (2005) (discussing the contribution of "soft law" in the process of European integration); Zumbansen, The Privatization of Corporate Law?, supra note 137.

174. See Moore, supra note 123, at 719-21.

175. See, e.g., Posner, supra note 124, at 2.

176. "In the hard v. soft controversy, the two genealogies provide the advocates of soft law with a vast armory of rhetorical arguments highlighting the virtues of soft harmonization and obliterating its blind spots and perverse effects. Rhetorical emphasis on organic spontaneity eclipses the fact that, at a merely instrumental level, soft law tools often prove deficient as to implementation and effectiveness, at times triggering unpredicted and counterproductive effects. At the level of policy objectives, celebration of pluralistic participation obscures the fact that soft law mechanisms, while involving a plurality of actors, are prone to reinforce entrenched power hierarchies, privileging visible and influential actors, and failing to take into account more marginal agendas. Similarly, accentuating the informal and gradual nature of soft harmonization allows its proponents to leave larger distributive questions unaddressed." Anna Di Robilant, Genealogies of Soft Law, 54 Ам. J. Comp. L. 499, 553 (2006).

177. Gunther Teubner, Substantive and Reflexive Elements in Modern Law, 17 Law \& Soc. Rev. 239 (1983). 


\section{B. Contract in Fragmented Legal Discourses}

In this vein, we might be well advised to regard contracts as instruments of communication in a fragmented, decentered, and disembedded collision of different discourses. In this understanding, ${ }^{178}$ contractual governance with the aim of bringing about a legal (contractual) regime compatible with an overriding policy or a greater program of social justice is a non-starter, because if it is associated with a particular social goal, any single contract is seen as a volatile and fragile combination and instable cluster of different contracts. Contracts, in this view, reflect society's differentiation into many, highly specialized areas of social activity. This approach sees contracts as constituting a radicalized form of an endless self-reproduction of differences, which reflects and is intimately linked to the eternal destruction of societal unity into fragmented, functional societal discourses. ${ }^{179}$ Certainly, the price paid for this clear view of the chaos is the loss of a distinctly political perspective on legal regulation. In the background of a deconstructivist model of contractual unity lies, to be sure, the deconstruction of any hierarchical framework within which to situate the political system, the state, or the market. Assuming a "society without pinnacle or centre," This approach to contract law leads us into a world of autopoietic self-reproduction of contractual governance norms and instruments. Is it a post-political world?

This question is at the center of our attempt to translate the Legal Realist critique into our day. In other words, why is it that even where we can witness a far-reaching extension of public power into the private sphere, either by direct intervention, by delegation, or by adjudication, we are still often confronted with a more or less insurmountable divide between the public and private? Or, to take up the critique made by Duncan Kennedy, why is it that we have come nowhere near understanding and potentializing what it really means when we assign the connotations of either public or private to a societal function ? $^{180}$ His recent obser-

178. Gunther Teubner, Contracting Worlds: The Many Autonomies of Private Law, 9 Soc. \& Legal STud. 399, 403 (2000) ("Contracting that is supposed to play its multifaceted role today must do so under the new condition of fragmentation of global society into a plurality of specialized discourses."); see David Campbell, The Limits of Concept Formation in Legal Science, 9 Soc. \& LEGAL Stud. 439 (2000); Ian R. Macneil, Contracting Worlds and Essential Contract Theory, 9 Soc. \& Legal Stud. 431 (2000).

179. Gunther Teubner, After Privatisation? - The Many Autonomies of Private Law, in From DisSONANCE To SENSE, supra note 68 , at $51,53$.

180. See Kennedy, supra note 94 , at 1712 (arguing that by contextualizing it still remains impossible to explain the character of the choice between different "sets of values and visions of the universe" underlying the choice of standards and rules). 
vation that adjudication has long been usurped by the conservatives and turned against the progressives through an intricate depoliticization, driven and promoted by a balancing process of allegedly neutral principles, ${ }^{181}$ is a powerful critique of the ongoing normalization and invisibilization of ideological struggles. ${ }^{182}$ In other words, it remains a first-order challenge to reject any contention that aims at separating law from morality instead of recognizing legal decisionmaking as fundamentally resting on moral choice along a continuum. ${ }^{183}$ The task it sets out, however, remains daunting. In which way ought we approach the repoliticization and de-neutralization of the currently intricate mixture of formalism and paternalism?

It should be clear, after Legal Realism, Critical Legal Studies, and a Feminist Legal Theory Critique of the use of the public-private dichotomy in the delineation of rights, duties, and empowerments, ${ }^{184}$ that contractual governance of a postindustrial welfare state, whether in terms of democratic participation, ${ }^{185}$ effective governance, ${ }^{186}$ or a "constitutionalization" of private law, ${ }^{187}$ must endorse a nonunifying understanding of the public-private divide in one way or the other. The first step, one already contemplated, as we have seen, by the Legal Realists, was to point to the ideological nature of the conceptual divide and to build, on this identification, a far-reaching critique of property rights and laissez-faire jurisprudence. ${ }^{188}$ The development of the regulatory state in the twentieth century only underlines that there is something fundamentally wrong with the general distinction between a sphere of public law and one of private law. Such a doctrine of separation would certainly stand in contrast to the evidence and the theory of the

181. See generally Kennedy, supra note 85 (drawing a distinction between law derived from doctrines and those from a normative system).

182. Caruso, supra note 87 , at 689-90.

183. Duncan Kennedy, The Political Stakes in "Merely Technical" Issues in Contract Law, 10 Eur. Rev. Priv. L. (Special Issue) 7, 23 (2001).

184. Nancy Fraser \& Linda Gordon, Dekodierung von "Abhängigkeit": Zur Genealogie eines Schlüsselbegriffs des amerikanischen Wohlfahrtsstaats, 26 KRITische Justiz 306 (1993).

185. E.g., Aman, supra note 69, at 95-96; Martin Shapiro, Administrative Law Unbounded: Reflections on Government and Governance, 8 Ind. J. Global Legal Stud. 369, 375-77 (2001).

186. E.g., Stewart, supra note 66.

187. Marc Amstutz, Andreas Abegg \& Vaios Karavas, Civil Society Constitutionalism: The Power of Contract Lazv, 14 Ind. J. Global Legal Stud. 235 (2007); Calliess, supra note 137, at 206; see also Zumbansen, supra note 58; Rudolf Wiethölter, Just-ifications of a Law of Society, in Paradoxes and Inconsistencies in the Law 65 (Oren Perez \& Gunther Teubner eds., 2006).

188. Hale, supra note 38 , at 470 ; Hale, supra note 40 , at $603-06$. For a recent critique, see Daniela Caruso, Private Law and Public Stakes in European Integration: The Case of Property, 10 Eur. L.J. 751 (2004). 
twentieth century interventionist ${ }^{189}$ and the mixed economy of the welfare state. ${ }^{190}$ But, it is not only since various forms of public intervention and regulation of social interaction that the allegedly private nature of these relationships has come into doubt. ${ }^{191}$ Because there never was a pure private law relationship without public dimensions, Elizabeth Mensch observed in 1981: "Since ownership is a function of legal entitlement, every bargain ... is a function of the legal orderincluding legal decisions about whether and to what extent bargained-for advantages should be protected as rights. It is therefore wrong to dissociate private bargaining from legal decisionmaking: The results of the former are a function of the latter." 192 The public-private divide, therefore, is inherent to any element of private law and of public law as well. This account, then, not only goes beyond the well-known reading of welfarist intervention into private spheres and beyond newer contentions of the mixed, public-private nature of contemporary regulatory governance; ${ }^{193}$ it also radically situates the public nature of private well before any such intervention.

It seems obvious that such a critique is especially needed in the context of the presently launched return to formalism in contract law. ${ }^{194}$ The field of dispute, however, is not as clear cut as it might seem at first. Whereas the critique by the Legal Realists focused primarily on clearly visible class and wealth divides, evidenced by market concentration and discretion on the one side and dependence and lack of influence on the other, the present assertions of a need for formalism seem to speak to more complex regulatory arrangements. Or do they? Where authors such as

189. Michael Stolleis, Die Entstehung des Interventionsstaates und das öffentliche Recht, 11 ZeITschrift Für Neuere Rechrsceschichte 129 (1989).

190. See Frankenberg, supra note 64, at 82; Habermas, supra note 110 , at 55.

191. Kennedy, supra note 91, at 566-68.

192. Mensch, supra note 76, at 764 .

193. See, e.g., Vincent-Jones, supra note 12; Peter Vincent-Jones, Contractual Governance: Institutional and Organizational Analysis, 20 Ox ford J. Legal Stud. 317, 318-19 (2000).

194. See Robert E. Scott \& Paul B. Stephan, The Limits of Leviathan: Contract Theory and the Enforcement of International Law 105 (2006) ("The evidence suggests that an attempt to extend formal enforcement to nonverifiable contract terms - such as the obligation to adjust terms in good faith - is likely to impair the efficacy of those informal means of enforcement that rely on reciprocity norms."); Schwartz \& Scott, supra note 6, at 557 (arguing that trustworthiness is likely to be built only in smaller, homogeneous communities); Scott, supra note 48 , at 848 (arguing that courts should "accept the limits imposed by legal formalism and interpret the facially unambiguous terms of disputed contracts literalistically"); Scott \& Triantis, supra note 78, at 818-21 (arguing for a combination of precise and vague terms in contract design on the basis, that even the choice of vague terms will invoke courts' reliance on business community benchmarks, but arguably still lower costs in contractual design). 
Robert Scott and Alan Schwartz emphasize the need for courts to withhold from introducing far-reaching duties into contractual arrangements ex post facto, they purport to speak in the interest of business communities in a stability and reliance of expectations. These authors argue that in small, homogenous communities contract parties will be better served when relying on and investing in trustworthiness in their dealings. ${ }^{195}$ Courts, by contrast, run the danger of stifling these self-enforcing norms in a well-functioning community by introducing another set of duties on which the parties did not agree. But what, we may ask, is the difference between their contention and that made by relational contract scholars as to the long-term perspective of adaptable, renegotiable contract structures? ${ }^{196}$ What, we may ask, is the difference between Professors Scott and Schwartz's acceptance that courts still must play a role in resolving conflicts between parties and the contention, recently made by Roy Kreitner, that contracts are embedded framework structures? ${ }^{197}$ We can here only indicate the direction in which answers to this puzzle might be found. Much of the puzzle's very nature is the seeming inability either to find a solution to the problem of incomplete contracts, or gaps in contractual arrangements, or to reach consensus based on which greater theory one may set out to fill such gaps. It seems that whereas those scholars who have written in favor of a socialization of contract with regard to an expansion of contractual liability in the twentieth century, ${ }^{198}$ others prefer to free contractual relations from such allegedly undue judicial interventions. It seems, however, that most of the attempts to return to the parties' true intentions cannot be achieved without eventually introducing a certain level of

195. Schwartz \& Scott, supra note 6 , at 557.

196. See Kreitner, supra note 48, at 463 (highlighting the influence of Ian Macneil's work on law and economics scholars).

197. "Contract law is indeed a regime that facilitates consent-based obligation. But in order for such a regime to operate successfully, it cannot simply ignore or extrude the species of obligations that lie at its borders. In order for contract law to function, it must regulate obligation well beyond explicit consent. Contract law is an infrastructure: its most important societal role is to supply frameworks for cooperative activity. Like the proper functioning of say, a highway, contract depends not only on written rules of the road, but also on the reliability of contextual practices. Courts cannot ignore those practices any more than they can decide disputes without recourse to language." Id. at 430 .

198. See, e.g., Kennedy, supra note 91. For the German perspective, see Anton Menger, Das Bürgerliche Recht und die besitzlosen Volksklassen (1890); Reinhard Damm, Privatautonomie und Verbraucherschutz-Legalstruktur und Realstruktur von Autonomiekonzepten, 50 VERS1cherungsrecht 129 (1999); Dieter Hart, Zur konzeptionellen Entwicklung des Vertragstechts, 29 Die Aktiengesellschaft (AG) 66 (1984); Maurer, supra note 100. 
value judgment that drives contract interpretation..$^{199}$ One cannot, indeed, escape the impression that much more is at stake here than merely a formalist approach to contract interpretation, ${ }^{200}$ one that is indeed so formal that it does not shy away from proposing that a narrow evidentiary approach to contract interpretation could reduce the danger of courts' over reach. ${ }^{201}$

\section{Form and Substance of the Law of Contract}

Again, our question: why do CLS scholars today still struggle to fully resolve our concerns over the public-private interface? The above studied recent assessments of the relationship between social norms and law have illustrated the achievements of the critical legal studies approach deconstructing the artificial character of this very distinction. But the preceding discussion has also shown that CLS still owes us a convincing account of how to replace this distinction. We have seen that CLS's identification of the distributory and, thus, political choices that lie at the heart of legal decisions does not yet amount to an adequate reformulation of the political dimension of today's contractual regimes. CLS scholars, like the Realists before them, have been successful in identifying the underlying political, moral nature of legal reasoning. But does this identification of substantive foundations of legal reasoning go far enough in addressing the particularly contested nature of contemporary contractual regulation? CLS scholars, like the Legal Realists, mounted their critique of formalism to overcome the insulation of formal law from the sphere of political decisionmaking. This functionalism, which characterized much of the Realists' work, ${ }^{202}$ defined itself in two directions. In one direction, it opposed formalism's alleged neutrality as an ideological cover placed over real political choices. In the other direction, it embraced the possibility of instrumentalizing law for social goals. While being aware of the contested-

199. In a masterful article, Paddy Ireland has shown this process at work at the heart of the contractarian theory of the firm. Paddy Ireland, Shareholder Primacy and the Distribution of Wealth, 68 Mod. L. Rev. 49 (2005).

200. Kreitner, supra note 48, at 437 ("The justification for formalism and its particular application flows from that much broader theory of contract. Thus the local application of formalism, and its particular brand of instrumentalism, is part of a wider theory that is not limited to contract, or to private law.").

201. Schwartz \& Scott, supra note 6, at 569.

202. See James M. Landis, The Administrative Process (1938), with regard to the pursuit of policy through administrative agencies; Felix S. Cohen, Transcendental Nonsense and the Functional Approach, 35 Colum. L. Rev. 809, 821-2, 839 (1935) (with regard to contractual agreements). 
ness of such goals and of the differences among societal interests, the Realists believed in the possibility of law in advancing social change.

While CLS shared the first contention with regard to the political content of legal decisions, it took an increasingly more ambivalent position towards the second. Although CLS embraced the Realists' insight that law is embedded in moral and political choices, ${ }^{203}$ it was much more skeptical of the possibility of using law for social change. ${ }^{204}$ This disenchantment with law as a means of social change, which occurred in the United States with the transition from legal theory concentrated on social, economic and political interests to a highly fragmented, so-called post-modern universe of conflicting values and rationalities, ${ }^{205}$ coincided with the emergence of so-called Reflexive Law in Germany in the late 1970s and early 1980s. Reflexive Law emerged as a reaction to the disillusionment with a fullblown welfare state's hubris in believing itself able to resolve societal conflicts through legal regulation. ${ }^{206}$ Both movements, CLS and Reflexive Law, understood that the Realists' project of questioning, or perhaps even overcoming, "form" through "substance" had suffered from the fundamental flaw of overburdening democratic institutions with the task of facilitating a consensus with regard to the content of that substance. For CLS, this eventually led to a proliferation of "schools" in response to the "irreducible ethical irrationality of legal judgment."207 For Reflexive Lawyers, the realization of form and substance as two sides of the same coin prompted the conceptualization of a theory that radicalized the notion of legal formality. Law was here understood as formal in the sense that it consisted only of legal rules internal to the legal system, through which it would "address" or "translate" conflicts arising in the political or the economic system. This autonomy of law was radical in that it identified both law's distinctness from and exposure to other social systems. This shift in perspective allowed for a better ap-

203. See Duncan Kennedy, The Political Stakes in "Merely Technical" Issues of Contract Law, 10 Eur. Rev. Priv. L. 7 (2001).

204. See e.g., Duncan Kennedy, The Critique of Rights in Critical Legal Studies, in Lefr Lecalism/ Left Critique 178, 206 (Wendy Brown \& Janet Halley eds., 2002) (underlining how the expansion of increasingly specialized rights made it harder to conceptualize these very rights as universal).

205. See Duncan Kennedy, Three Globalizations of Law and Legal Thought: 1850-2000, in THE New Law and Economic Development: a Critical Appraisal 19 (David M. Trubek \& Alvaro Santos eds., 2006).

206. See e.g., Gunther Teubner, Substantive and Reflexive Elements in Modern Law, 17 Law \& Soc'y Rev. 239 (1983).

207. Duncan Kennedy, The Disenchantment of Logically Formal Legal Rationality, or Max Weber's Sociology in the Genealogy of the Contemporary Mode of Western Legal Thought, 55 HAst. L. J. 1031, $1076(2004)$. 
preciation of what the law could do and what it could not. ${ }^{208}$ Consequently, issues of legitimacy would become concerns of the political system, while the distinction between legal and illegal would be the core defining "code" of the legal system. This reconceptualization of law led to a dramatic reversal of what was previously understood as formalism and functionalism in legal reasoning.

Formalism, as it was attacked by the Legal Realists, had been based on the contention that legal reasoning rested and built on an internally logical system of rules and principles, which in turn were embedded in a liberal order. The central opponent of formalism was functionalism, which depicted the belief that law was a means of pursuing certain social and political ends. The Legal Realists had attacked legal formalism with the contention that formalism's aspiration to justify legal decision with reference to a particular unity and even logical coherence of law was fundamentally flawed. The Realists had attacked legal formalism as hiding real, existing power differences and thereby serving to entrench those already in power. ${ }^{209}$ In response, functionalism had rejected this alleged inner coherence of law and instead defended a model that first challenged legal formalism's contentions of its neutral nature and then embraced law as an instrument of social change. The content of that change was discerned with regard to the needs of society. Functionalism, thus, was the exact opposite of formalism in that it was understood as being ethical in content. Functional interpretation of law therefore built on the belief that the law was a central instrument in pursuing particular social goals.

Reflexive Law, in turn, seemed to return to a point prior to the critique launched by Legal Realists by embracing the idea of legal formality on the one hand and by understanding law as being functional in the sense that it constantly receives impulses and directions from other social systems. It is this ambiguous nature, its formality reformulated as (operational) closure and its functionality understood as (cognitive) openness ${ }^{210}$ that places Reflexive Law in arguably dan-

208. Calliess, supra note 58; Philip Selznick, Law, Society, and Industrial Justice (1969); Zumbansen, supra note 58; Gralf-Peter Calliess, Lex Mercatoria: A Reflexive Law Guide To An Autonomous Legal System, 2 German L.J. 17 (2001), available at http://www.germanlawjournal. com/article.php?id=109; Teubner, supra note 177; Rudolf Wiethölter, Materialization and Proceduralization in Modern Law, in Dilemmas of Law in the Welfare State, supra note 96, at 221; Rudolf Wiethölter, Proceduralization of the Category of Law, in Critical Legal. Thought: AN American-German Debate 501 (Christian Joerges \& David Trubek eds., 1989); Peer Zumbansen, Comparative Law's Coming of Age? Twenty Years after 'Critical Comparisons', 6 German L.J. 1073 (2005).

209. Morton Horwitz, The Rise of Legal Formalism, 19 Am. J. Leg. Hist. 251 (1975).

210. See Gunther Teubner, Autopoiesis in Law and Society: A Rejoinder to Blankenburg, 18 Law \& Soc'y Rev. 291 (1984); Niklas Luhmann, Operational Closure and Structural Coupling: The Differ- 
gerous proximity to contemporary trends to depoliticize and neutralize law in regulatory theory and practice. Formalism and functionalism have today ceased to represent two ends of the spectrum. Instead, they have been ideologically joined in that formalism is being understood as the absence of legal regulation, while functionalism reformulates the function of law as a form of mere expert management. Reserving only genuinely "legal" questions to the law (such as the application of legal rules for example to assign property), the bulk of regulation is believed to be governed by resorting to market expertise. The combination of formalism and functionalism effectively invisibilizes the political stakes that underlie the allocation of both legal and market expertise. ${ }^{211}$

This brings us back to our assessment of contemporary developments in contract law. As we will discuss in more detail in the following, concluding section, contractual governance constitutes the heart and center of contemporary regulatory concepts. Its very ubiquitousness gives striking testimony of a reflexive turn in contractual governance. For some decades now, contracts have been central to both the dramatic transformation of the twentieth century welfare state and the consolidation of global commercial relations. These changes, which have on the domestic level been depicted as "privatization" and outside of the nation state as "globalization," are really parts of the same development: a dramatic erosion of the political authority that in the Western tradition we have commonly associated with the state. This erosion of state authority, which constitutes at its core a transformation of political authority, informs the ongoing disenchantment with theories of social cohesion, common values and shared convictions. This constellation challenges any contention of societal consensus. Society, in the dictum of the late German sociologist Niklas Luhmann, has neither center nor apex. It must instead be understood as a "world society," a society comprised of multiple social rationalities the institutional architecture of which has replaced the image of a state-centered political order. ${ }^{212}$ Society, in this view, is made up of different spheres of societal functions, each unfolding with regard to its own language and rationality. Such a concept of society is based on an extremely fragmented, diversified, and non-unified- "functionally differentiated"- - understanding of society.

What does this mean for law? Given the particular formality and functional-

entiation of the Legal System, 13 CARD. L. REv. 1419 (1992).

211. For a critique, see Peer Zumbansen, Law after the Welfare State, or The Ironic Turn of Reflexive Law, (unpublished manuscript on file with author).

212. Niklas Luhmann, The World Society as a Social System, 8 Int. J. General Systems 131 (1982). 
ity of law, which we depicted above, its particular status as a normative theory is formidably challenged. Yet, from the perspective of Reflexive Law, which conceptualizes law in light of the sociological account of a functionally differentiated society, it could be said that law continues to be normative, just not in one singular way. It is neither religious belief, economic rationality nor "social" justice that determines law's content. Instead, law incorporates societal conflicts by exclusively "addressing" them through its internal code. It is thereby always exposed to and involved in these conflicts. As such it could be said that the law, instead of reflecting the values of individualism, collectivism or communitarianism in its totality, will only in parts reflect these or other societal values. The law adapts to the functional differentiation of society by multiplying its normative character in reaction to the multiple rationalities of society.

As a consequence, the way in which the law is normative is not as straightforward as perhaps wished for by the Legal Realist (or the Natural Lawyer) or feared by the Formalist (or Law and Economics scholar). Being cognitively open to the manifold societal conflicts, but operationally closed in its application of legal/illegal, the legal system reformulates societal conflicts arising in the political, economic, religious or scientific systems as legal conflicts. ${ }^{213}$ Once a legal solution is found, it is given back to the specific societal area in which it arose. Law, by necessity, will always struggle with this task of translating, one that is experienced by lawyers as one of lawmaking, even if it is called interpretation.

The point here is that whether it is the Legal Realist or the Neo-Formalist who appears to explain the rationality of contracts as being exclusively economic, ${ }^{214}$ both are likely to approach the law with a certain concept, which is-as we have seen-too limited to account for the complexity of either contractual governance regimes in particular or of society in general. In short, contracts, seen through the theoretical lens just described, must indeed be perceived as a highly sensitive framework, concept and instrument with which most divergent societal expectations and rationalities can be brought into confrontation, channeled, reformulated, and sustained. To understand that contracts fulfill this very function as linkages and mediators-structural couplings ${ }^{215}$ - between different societal rationalities should be at the outset of any critique of party autonomy or judicial intervention. Secondly, both the Realist and the Neo-Formalist should be mind-

213. Gunther Teubner \& Peer Zumbansen, Rechtsverfremdungen: Zum gesellschaftlichen Mehrwert des zwölften Kamels, 21 Zeitschrift für Rechtssoziologie 189 (2000).

214. Posner, supra note 25.

215. LuhmanN, supra note 167 , at 381-422; Luhmann, supra note 210. 
ful that their respective understandings of society are inadequate to capture the wealth of societal interaction that each is silently hoping contractual governance might be able to promote. The inadequacy of both concepts to realize the full potential of contract and society is evidenced by the insistence of each on "getting it right." The observation of a functionally differentiated society suggests, however, that law in a complex contemporary society can only function in an experimental, reflexive, and tentative way. ${ }^{216}$ This reconceptualization of society correlates with an emerging, strikingly different understanding of what is meant by the "state" in contemporary regulatory discourse. ${ }^{217}$

\section{Functionalism, Reflexive Law, and the Law of Society}

As "governance by contract" has become a central regulatory concept in contemporary discourses and policymaking, whether as part of domestic privatization and law reform programs or as a central element of law-and-development projects, we are in an important period of reconsidering our respective contentions with regard to contractual justice. On the one hand, an appreciation of a more complex understanding of society leads to a more cautious, layered, both historically shaped and sociologically informed understanding of law. As a consequence, the current turn to contract could be understood as an example of a return to historical forms of "social law"218 or "living law." 119 Yet, the current invocation of contract and norms occurs within the imperialist reach of economic reasoning, which for the time being seems to effectively eclipse a successful coupling of contract with other social systems. The present dominance of economic thinking in legal reasoning in general, and in contract law theory in particular,

216. See Teubner, supra note 177.

217. See Karl-Heinz Ladeur, Der Staat gegen die Gesellschaft: Zur Verteidigung der Rationalität der Privatrechtsgesellscraft (2006) (highlighting the need to reach beyond mere concessions as to the changing nature of the state in order to begin to adequately address the relationship between the state and law in a radically decentred knowledge society).

218. Georges Gurvitch, Sociology of Law 167 (1947) ("'Social Law' is a law of objective integration in the 'We', in the immanent whole. It permits the subjects, to whom it is addressed, to participate directly in the whole, which in turn effectively participates in jural relations.").

219. Eugen Ehrlich, Fundamental Principles of the Sociolocy of Law 493 (1975) ("The living law is the law which dominates life itself even though it has not been posited in legal propositions. The source of our knowledge of this law is, first, the modern legal document; secondly, direct observation of life, of commerce, of customs and usages, and of all associations, not only of those that the law has recognized but also of those that it has overlooked and passed by, indeed even of those that it has disapproved."). 
expresses a troubling return of formalist/functionalist thinking. The already alluded to erosion of the state from below and from above forms the framework of this current turn. As a consequence of this erosion, contemporary legal consciousness seems increasingly marked by a striking forgetfulness with regard to the early twentieth century's critique of the use of the public-private distinction to mark the boundaries between the political sphere of the state and the allegedly apolitical private sphere of the market. Instead, all that remains of that critique is today's favoritism of private ordering over state intervention. The current endorsement of law in the facilitation of processes of societal self-regulation thus preserves only an extremely reduced and formalistic role for law and legal institutions. As the latter are charged primarily with the duty to promote and to safeguard effectiveness, reliability, and predictability for market participants' transactions, any evocation of a "public" purpose to be pursued by political means is rejected as unduly fettering private autonomy. The state is to assume a functional role in facilitating societal processes of self-regulation. To the degree, however, that a functionalist view of societal governance prioritizes economic growth and development, private economic ordering is given dominance over political governance in seemingly technical, neutral terms. ${ }^{220}$

Today, it seems that a productive assessment of contractual governance must both incorporate and go beyond a renewal of the Legal Realist critique of the ideology of private contract and property. To address adequately the complexity of contractual arrangements now central to processes of societal ordering, any understanding of contract must take seriously the differentiation of societal activity. Central to this critique is the recognition that it is not enough to reject the public-private distinction as an ideological mask that covers up the legal construction of the private sphere. Instead, the public-private distinction must be understood as a foundational paradox inherent in any reference to a legal right. Its paradoxical nature lies in the fact that on both sides of the distinction the other will always reappear; that is, there is no public without the private, and vice versa. ${ }^{221}$ In light of this paradox that lies at the heart of an understanding of society as a term referring to different societal rationalities in constant communication and irritation with each other, the core contention of this paper is that

220. Critical Law and Development scholars have begun to deconstruct powerfully this second arrival of functionalism and formalism and to uncover the particularly troubling depoliticization inherent in the current employment of rule of law arguments in law reform contexts. See, e.g., Rittich, supra note 63.

221. Peer Zumbansen, Sustaining Paradox Boundaries: Perspectives on the Internal Affairs in Domestic and International Law, 15 Eur. J. INT'L L. 197 (2004). 
contracts cannot be understood with reference only to one particular rationality, be that economic, productive (scientific, contextual), or normative. Instead, each contract must be seen as a forum where different rationalities from economic exchanges, social production (involving different forms of knowledge and expertise), ${ }^{222}$ and normative promises (utopia, trust, loyalty) are colliding. What is the law to do with this fragmentation of the concept of contract?

The perception of a contract's different rationalities has important repercussions for both governance by contract and governance of contract. While contractual governance describes a complex, multidimensional arrangement of societal exchanges (governance by contract), the latter describes a particularly challenging role for legal governance (adjudication, regulation, and enforcement of contracts). In this vein, the current emphasis on "governing contracts" reflects on the way that the law is intimately and irreversibly implicated in the evolution of particular societal discourses. Legal regulation of contract, in this reading, requires the law constantly to translate conflicting, overlapping, and diverging societal rationalities into its own legal language. As the reflexive law of contractual governance is engaged in this process of translation, it transforms its tension between form and substance into a dangerous, yet existential reflexive practice on the employed formal procedures and substantive assessments. Its oscillation with other societal rationalities is the death of this societal law. It is from this death that it will reemerge as the law of society. 
International Journal of

\section{Feminist Approaches to Bioethics}

...provides $a$ forum within

bioethics for feminist thought and debate.
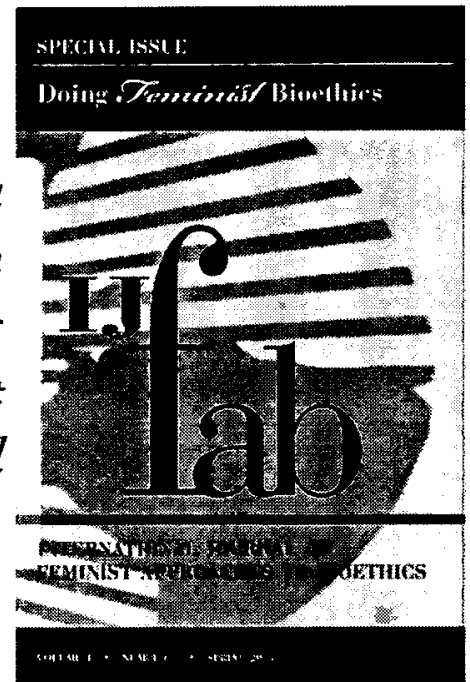

Edited by Mary C. Rawlinson

p- ISSN: $1937-4585$

e - ISSN: 1937-4577

The International Journal of Feminist Approaches to Bioethics (IJFAB) provides a forum within bioethics for feminist thought and debate. Sponsored by the International Network on Feminist Approaches to Bioethics, IJFAB welcomes feminist scholarship on ethical issues related to health, health care, and the biomedical sciences. IJFAB aims to demonstrate clearly the necessity and distinctive contributions of feminist scholarship to bioethics.

Institutions:

print $\$ 85.00$

electronic $\$ 76.50$

print \& electronic $\$ 119.00$
Individuals:

print $\$ 42.00$

electronic $\$ 37.80$

print \& electronic $\$ 46.20$

Now available 